GAO

Report to the Chairman, Committee on Education and the Workforce, House of Representatives

October 2003

\title{
PUBLIC SCHOOLS
}

Comparison of

Achievement Results

for Students Attending

Privately Managed and

Traditional Schools in

Six Cities

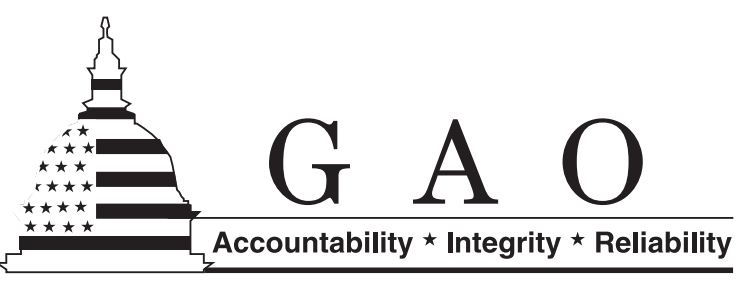




\section{G A O Accountability - Integrity $\cdot$ Reliability Highlights}

Highlights of GAO-04-62, a report to the Chairman, Committee on Education and the Workforce, House of Representatives

\section{Why GAO Did This Study}

Over the last decade, a series of educational reforms have increased opportunities for private companies to play a role in public education. For instance, school districts have sometimes looked to private companies to manage poorly performing schools. The accountability provisions of the No Child Left Behind Act of 2001 may further increase such arrangements because schools that continuously fail to make adequate progress toward meeting state goals are eventually subject to fundamental restructuring by the state, which may include turning the operation of the school over to a private company.

GAO determined the prevalence of privately managed public schools and what could be learned about student achievement in these schools from publicly available sources. To do so, GAO examined existing data on the number and location of privately managed schools and reviewed a variety of reports on student achievement. In addition, GAO compared standardized test scores of students attending privately managed public schools with scores of students attending similar traditional public schools. GAO identified privately managed schools that had been in operation for four years or more in 6 large cities and matched these schools with a group of traditional schools serving similar students. GAO then analyzed student scores on state reading and math tests at selected grade levels, controlling for differences in student populations.

www.gao.gov/cgi-bin/getrpt?GAO-04-62

To view the full product, including the scope and methodology, click on the link above. For more information, contact Marnie Shaul at (202) 512-7215 or shaulm@ gao.gov.
PUBLIC SCHOOLS

\section{Comparison of Achievement Results for Students Attending Privately Managed and Traditional Schools In Six Cities}

\section{What GAO Found}

The number of public schools managed by private companies has tripled in the last 5 years according to data compiled by university researchers, although such schools comprise less than 0.5 percent of all public schools. In the 2002-03 school year, nearly 50 private companies managed over 400 public schools nationwide. These companies managed schools in 25 states and the District of Columbia, with about one-half of the schools located in Arizona and Michigan. Information on student achievement at these schools was available in the form of state- or district-issued school report cards and annual reports issued by the management companies. Although these reports provided valuable descriptive information, they were generally not designed to answer research questions about the relative effectiveness of privately managed schools compared with traditional schools in raising student achievement. Consequently, GAO conducted test score analyses that provide further insight into student achievement in these schools.

Location of Public Schools Operated by Private Management Companies in School Year 2002-03

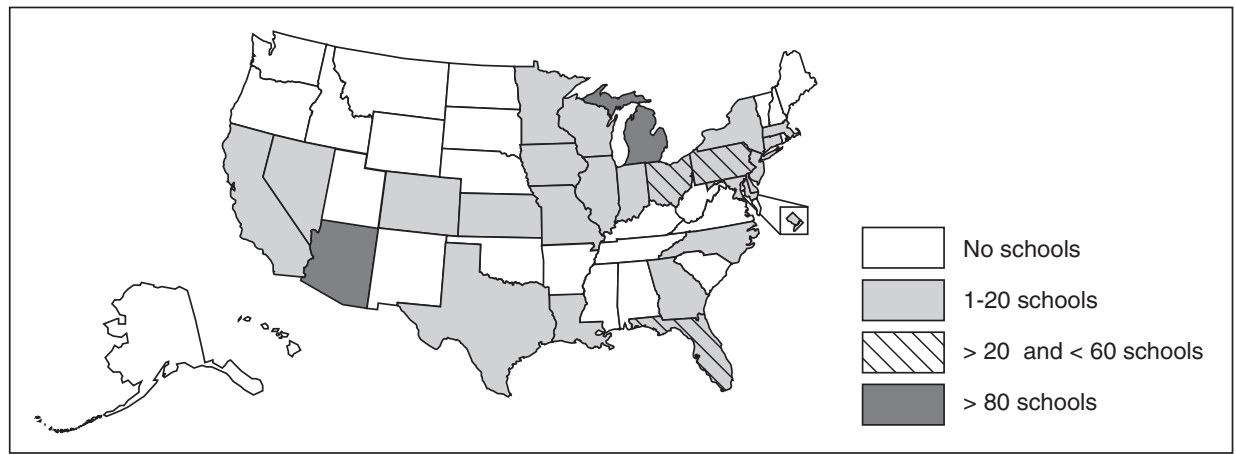

Sources: GAO analysis of Arizona State University data; copyright @ Corel Corp. All rights reserved (map).

GAO's analyses of student test scores in 6 cities yielded mixed results. Scores for $5^{\text {th }}$ grade students in Denver and San Francisco were significantly higher in both reading and math in two privately managed schools when compared with traditional schools serving similar students. However, $4^{\text {th }}$ grade scores in reading and math were significantly lower in a privately managed public school in Cleveland, as were $5^{\text {th }}$ grade scores in two privately managed schools in St. Paul. In Detroit, where eight privately managed schools were studied, reading and math scores of $5^{\text {th }}$ graders in privately managed schools were generally lower. In Phoenix, GAO found no significant differences. GAO's results are limited to the schools and grade levels examined and may not be indicative of performance at other schools. 


\section{Contents}

\section{Letter}

Results in Brief

Background

Number of Schools Managed by Education Management

Companies Is Increasing; Descriptive Information on

Achievement Widely Available

No Consistent Pattern of Differences in Scores on State Tests

Found between Public Schools Managed by Private Companies

and Comparable, Traditional Elementary Schools

Concluding Observations

Agency Comments

Scope and School Selection

Measures and Analytic Methods

Limitations of the Analysis

Tables of Regression Results for Differences in Student Achievement Scores on State Assessments

\begin{tabular}{lll}
\hline Appendix IV & GAO Contacts and Staff Acknowledgments & 55 \\
& GAO Contacts & 55 \\
& Acknowledgments & 55
\end{tabular}

\section{Tables}

Table 1: State Assessment Schedules and Tests of Reading and Mathematics through Fifth Grade in Six Cities in School Year 2001-02

Table 2: School Characteristics of the Privately Managed Schools and Comparison Schools in Denver and San Francisco 
Table 3: School Characteristics of the Privately Managed Schools and Comparison Schools in Cleveland and St. Paul

Table 4: School Characteristics of the Privately Managed School and Comparison Schools in Phoenix

Table 5: Regression Results for Differences in Student Performance on State Assessments at the Privately Managed and Comparison Schools in Denver

Table 6: Regression Results for Differences in Student Performance on State Assessments at the Privately Managed and Comparison Schools in San Francisco

Table 7: Regression Results for Differences in Student Performance on State Assessments at the Privately Managed and Comparison Schools in Cleveland

Table 8: Regression Results for Differences in Student Performance on State Assessments at the Privately Managed School and Comparison Schools in St. Paul (School A Comparison)

Table 9: Regression Results for Differences in Student Performance on State Assessments at the Privately Managed School and Comparison Schools in St. Paul (School B Comparison)

Table 10: Regression Results for Differences in Student Performance on State Assessments at the Privately Managed and Comparison Schools in Phoenix

Table 11: Regression Results for Differences in Student Performance on State Reading Assessment at the Privately Managed and Comparison Schools in Detroit

Table 12: Regression Results for Differences in Student

Performance on State Math Assessment at the Privately

Managed and Comparison Schools in Detroit

\section{Figures}

Figure 1: Number of Public Schools Managed by Private Companies from School Year 1998-99 through 2002-03

Figure 2: Location of Public Schools Operated by Private

Management Companies in School Year 2002-03 and

Annual Number of States with Such Schools Since 1998-99

Figure 3: Number of Educational Management Companies from

School Year 1998-99 through 2002-03

Figure 4: Test Score Section of a Report Card for a Hypothetical

School in Colorado for School Year 2002-03 
Figure 5: Fifth Grade Reading Scores for the Privately Managed

School and Comparison Schools in Denver on the

Colorado Student Assessment Program

Figure 6: Fifth Grade Reading and Math Scores for the Privately

Managed School and Comparison Schools in San

Francisco on the Stanford-9 Achievement Test

Figure 7: Fourth Grade Reading Scores for the Privately Managed

School and Comparison Schools in Cleveland on the Ohio

Proficiency Test

Figure 8: Fifth Grade Reading and Math Scores for the Privately Managed Schools and Comparison Schools in St. Paul on the Minnesota Comprehensive Assessment Program

Figure 9: Fourth Grade Reading Scores for Privately Managed and Comparison Schools in Detroit on the Michigan Education Assessment Program

Figure 10. Fourth Grade Math Scores for Privately Managed and

Comparison Schools in Detroit on the Michigan Education Assessment Program

Figure 11: Fifth Grade Reading and Math Scores for the Privately Managed School and Comparison Schools in Phoenix

\begin{tabular}{ll}
\hline Abbreviations \\
NCLBA & No Child Left Behind Act of 2001 \\
LEP & limited English proficiency \\
OLS & ordinary least squares
\end{tabular}

This is a work of the U.S. government and is not subject to copyright protection in the United States. It may be reproduced and distributed in its entirety without further permission from GAO. However, because this work may contain copyrighted images or other material, permission from the copyright holder may be necessary if you wish to reproduce this material separately. 
October 29, 2003

The Honorable John A. Boehner

Chairman

Committee on Education and the Workforce

House of Representatives

Dear Mr. Chairman:

In the last decade, reports of failing schools and low student achievement have given rise to a variety of educational reforms that have expanded opportunities for private companies to play a role in public education. In some cases, school districts have looked to private companies to manage poorly performing schools with the expectation of improving scores on state achievement tests. The accountability requirements of the No Child Left Behind Act (NCLBA) of 2001 may further increase such arrangements because schools that continuously fail to make adequate yearly progress toward meeting state proficiency goals may be eventually subject to fundamental restructuring by the state, including turning the operation of the school over to a private management company. ${ }^{1}$

As the role of private companies in the management of public schools has developed, interest in students' academic performance at these schools has grown. In light of the expanding role for private companies in public education, we agreed with your office to determine the prevalence of public schools managed by private companies and to report on what can be learned about student achievement in these schools from publicly available information sources. In addition, we agreed to compare student achievement in elementary schools operated by private companies in large urban areas with student achievement in similar traditional elementary schools.

To determine the prevalence of privately managed schools, we obtained information from research organizations on the number and location of public schools that have both instructional and noninstructional services provided by private companies. We relied primarily on a 2002-03 annual report compiled by Arizona State University that tracks nationwide growth

${ }^{1}$ Public Law 107-110, Jan. 8, 2002. 
of for-profit educational management companies, the only such report of its kind we found. ${ }^{2}$ We selectively verified data in that report with information compiled by the National Center for Education Statistics, the Center for Education Reform, the National Association of Charter School Authorizers, and university researchers in Michigan and New Jersey. To locate publicly available information on student achievement in privately managed schools, we examined a variety of Internet Web sites, including state, district, and the larger private management company sites. We also reviewed studies conducted by the companies and by other researchers, as well as performance reports issued by state and district school officials to learn what has been reported about achievement at these schools.

To compare student achievement in public elementary schools operated by private companies with that at similar traditional schools, we analyzed individual student performance in specific grades on mandatory state tests of reading and mathematics. We identified 14 public elementary schools in larger urban areas across the country that had been continuously managed by private companies since the 1998-99 school year. These schools, managed by six private companies, were located in six cities: Cleveland, Ohio; Denver, Colorado; Detroit, Michigan; Phoenix, Arizona; St. Paul, Minnesota; and San Francisco, California. We matched each of the 14 schools with a set of 2 or more traditional public schools in the same city that were similar in terms of grade span, enrollment, student race and ethnicity, and the percentage of students with limited-English proficiency, disabilities, and eligibility for the federally subsidized free and reducedprice school lunch program. (See app. I for details on the procedures used to match schools.) Using test scores for the school years 2000-01 and 2001-02, we compared student scores in reading and math at one grade level in each of the 14 privately managed schools with scores of students in the same grade at the set of similar traditional schools. We also analyzed changes in individual students' test scores over time in the three cities where such data were available-Denver, Phoenix, and San Francisco.

Our analyses controlled for differences in characteristics of students attending the privately managed and traditional schools by using demographic characteristics—-such as those used in selecting similar

\footnotetext{
${ }^{2}$ Arizona State University researchers at the Education Policy Studies Laboratory compile annual data on the number of companies and their schools by school type, grade level, size of enrollment, year opened, and location. See Alex Molnar, Glen Wilson, and Daniel Allen, Profiles of For-Profit Education Management Companies 2002-2003, (Tempe: Arizona State University, Jan. 2003).
} 
traditional schools-and student mobility to the extent that these data were available for individual students. We use the word significant-as in significantly higher or lower-throughout this report to mean statistical significance at a 95-percent confidence level, not to refer to the importance of the difference. Our study is constrained to varying degrees by incomplete data for some locations and by the lack of information on the reasons that individual students enrolled in these schools. In addition, our findings about student performance are limited to the particular grades in the privately managed and traditional schools we studied and may not be indicative of other grades or schools. For this reason, we do not identify the specific schools or the associated management companies in our study by name. A detailed explanation of our methodology, study limitations, and data verification procedures are found in appendix I. We conducted our work from January to October 2003 in accordance with generally accepted government auditing standards.

The number of public schools managed by private companies has tripled in the last 5 years, according to data compiled by university researchers. Nevertheless, only slightly more than 400 public schools were privately managed in the 2002-03 school year, considerably less than 1 percent of all public schools. Managed by 47 private companies, these schools were located in 25 states and the District of Columbia, with about one-half located in Arizona and Michigan. Descriptive information about achievement at individual schools was widely available in the form of school report cards that identified the proficiency levels or achievement scores of students tested in the current year, relative to state standards and state or district averages. Three company reports presented information on changes in achievement over time for all their schools in one or more states. While providing useful information on student achievement, these reports were generally not designed to answer research questions about the relative effectiveness of privately managed schools compared with traditional schools.

Our analyses of scores on state reading and mathematics tests in selected grades did not show a consistent pattern of superior student performance between schools managed by private companies and demographically similar traditional public schools in six cities. In two cities, Denver and San Francisco, students at the privately managed schools had on average significantly higher reading and mathematics scores than students at similar traditional public schools. Students at these privately managed schools also demonstrated greater academic gains over multiple years. However, in two other cities, Cleveland and St. Paul, student scores in 
reading and math were significantly lower in schools managed by private companies compared with similar traditional schools. In Detroit, results were somewhat mixed, although scores tended to be lower in the privately managed schools - reading scores were lower in 6 of the 8 privately managed schools and math scores were lower in 7 of the 8 privately managed schools, compared with similar traditional schools. In Phoenix, there were no significant differences in either reading or math between students at the two types of schools. Our results are limited to the schools and grade levels examined and may not be indicative of performance at other schools. fairly recent phenomenon. Until the early 1990's, school districts contracted with private companies largely to provide noninstructional services, such as transportation, building maintenance, or school lunches. By the 1994-95 school year, however, the role of private companies had expanded to include instructional services in four school districts, as we reported in a 1996 GAO study. ${ }^{3}$ These early decisions by school districts to contract with private companies often followed years of frustration with low student achievement in these schools. Since that time, the growth of private for-profit educational management companies has been aided by financial support from the business community and by the opportunities states have offered for greater flexibility in the provision of education services.

Private for-profit management companies supply a wide array of educational and management services that may include providing the curriculum, educational materials, and key staff as well as payroll processing, busing, and building maintenance. The range and type of services vary by company, and to some extent by school within the company, as some companies have adapted their educational programs to the needs and interests of local areas. According to a study of for-profit educational management companies by Arizona State University, threequarters of schools operated by private for-profit management companies in school year 2002-03 served elementary grade students in kindergarten through fifth grade and in some cases continued to serve students in higher grades. The size of schools operated by private management

${ }^{3}$ See U.S. General Accounting Office, Private Management of Public Schools: Early Experiences in Four School Districts, GAO/HEHS-96-3 (Washington, D.C.: Apr. 19, 1996). 
companies varied from an enrollment of fewer than 100 students to more than 1,000 students, but averaged about 450. Several of the major companies reportedly served a predominantly low-income, urban, and minority student population.

Private companies operate both traditional public schools and public charter schools. Some states or districts contract with companies to manage traditional public schools-often poorly performing public schools. These schools are generally subject to the same set of requirements that govern traditional schools within the district. More commonly, companies manage charter schools - public schools that operate under agreements that exempt them from some state and district regulations but hold them accountable for improving pupil outcomes. Enrollment in charter schools generally is not limited to defined neighborhoods, but may draw from larger geographic areas than is the case for most traditional schools and must be open to all, without discrimination, up to enrollment limits. Like traditional public schools, charter schools receive public funds and may not charge tuition for regular school programs and services, but may charge for before- and after-school services, extended day kindergarten, or pre-kindergarten classes.

Public schools operated by private management companies, both traditional and charter, are subject to requirements of the NCLBA, including expanded testing requirements. Under this law, states must establish standards for student achievement and goals for schools' performance. Results must be measured every year by testing all students in each of elementary grades three through five and middle school grades six through eight, starting in school year $2005-06,{ }^{4}$ and by assessing how schools have progressed in terms of improving the performance of their students. Information from these tests must be made available in annual reports that include the performance of specific student subgroups, as defined by certain demographic and other characteristics. During the school years covered in our study, states were only required to test students in one elementary, one middle school, and one high school grade. Table 1 identifies the different state testing schedules and instruments for the elementary grades in school year 2001-2002 in the cities where we made test score comparisons.

\footnotetext{
${ }^{4}$ This requirement takes effect as long as specified amounts of federal funding are provided for test administration. For more on this subject, see U.S. General Accounting Office, Title I: Characteristics of Tests Will Influence Expenses; Information Sharing May Help States Realize Efficiencies, GAO-03-389 (Washington, D.C.: May 8, 2003).
} 
Table 1: State Assessment Schedules and Tests of Reading and Mathematics through Fifth Grade in Six Cities in School Year 2001-02

\begin{tabular}{lrl}
\hline City, state & $\begin{array}{r}\text { Elementary } \\
\text { grades tested }\end{array}$ & State test administered \\
\hline Phoenix, Arizona & $2-5$ & $\begin{array}{l}\text { Stanford Achievement Test, 9th } \\
\text { Edition }\end{array}$ \\
\hline San Francisco, California & $2-5$ & $\begin{array}{l}\text { Stanford Achievement Test, 9th } \\
\text { Edition }\end{array}$ \\
\hline Denver, Colorado & $3-5^{\text {a }}$ & $\begin{array}{l}\text { Colorado Student Assessment } \\
\text { Program }\end{array}$ \\
\hline Detroit, Michigan & 4 & $\begin{array}{l}\text { Michigan Educational Assessment } \\
\text { Program }\end{array}$ \\
\hline St. Paul, Minnesota & $3 \& 5$ & $\begin{array}{l}\text { Minnesota Comprehensive } \\
\text { Assessments }\end{array}$ \\
\hline Cleveland, Ohio & 4 & \begin{tabular}{l} 
Ohio Proficiency Test \\
\hline
\end{tabular}
\end{tabular}

Source: State education departments of the states shown.

${ }^{a}$ Reading was tested in all three grades, but mathematics was tested only in fifth grade.

Infrequent state testing is one of several factors that have hampered efforts to evaluate the impact of privately managed public schools on student achievement. To assess the impact of school management, researchers must isolate the effects of private management from the effects of other factors that could influence students' test scores, such as school resources or student ability. Ideally, this would be accomplished by randomly assigning students to either a privately managed school or a traditionally managed school, resulting in two groups of students generally equivalent except for the type of school assigned. However, random assignment is rarely practical, and researchers usually employ less scientifically rigorous methods to find a generally equivalent comparison group. For instance, in some cases, schools may be matched on schoolwide student demographic characteristics such as race or socioeconomic status. When such characteristics can be obtained for individual students in the study, validity is improved. In addition, validity is further improved when the progress of students can be followed over several years. However, if the data on individual student characteristics are unreliable or unavailable, as has often been the case, researchers experience difficulties developing valid comparison groups. Similarly, if individual test scores are available only for one grade rather than successive grades, researchers cannot reliably track the progress of student groups over time and compare the gains made by the two groups. In our 2002 report that examined research on schools managed by some of the largest education management companies, we found that insufficient 
rigorous research existed to clearly address the question of their impact on student achievement. ${ }^{5}$ Part of the reason that so few rigorous studies are available may stem from the difficulties inherent in this research.

Number of Schools
Managed by
Education
Management
Companies Is
Increasing;
Descriptive
Information on
Achievement Widely
Available

Number of Schools Managed by Education Management Companies Is

Increasing; Descriptive Information on Available

While Numbers Are
Increasing, the Percentage
of Public Schools Managed
by Private Companies
Remains Small

While Numbers Are Increasing, the Percentage by Private Companies Remains Small
Although the number of public schools operated by private, for-profit management companies has risen rapidly in recent years, these schools still comprise a very small proportion of all public schools nationwide. Largely charter schools, the 417 privately managed schools were located in 25 states and the District of Columbia in school year 2002-03, with about one-half in Arizona and Michigan. These schools were operated by 47 private management companies. Descriptive information about achievement in these schools was widely available in the form of individual school report cards that often provided comparisons with state or district averages, but often not with similar traditional schools. Three management company reports summarized achievement gains over time for all their schools in one or more states, using various methodologies to illustrate student performance. School and company reports provided useful information on student achievement, but generally were not designed to answer research questions about the effectiveness of privately managed schools compared with traditional schools.

In school year 2002-03, at least 417 public schools were operated by private for-profit management companies, according to Arizona State University researchers. ${ }^{6}$ This figure was three times greater than the number of schools operated by private management companies just 4 years earlier, when there were only 135 schools, as shown in figure 1. Over three-quarters of the 417 schools were charter schools, and they comprised about 12 percent of charter schools nationwide. Despite the sharp rise in the number of public schools operated by management companies, they represented a small proportion of all charter and

\footnotetext{
${ }^{5}$ See U.S. General Accounting Office, Public Schools: Insufficient Research to Determine Effectiveness of Selected Private Education Companies, GAO-03-11 (Washington, D.C.: Oct. 29, 2002).

${ }^{6}$ Arizona State University researchers list only schools operated by management companies that the researchers can positively identify as for-profits, but additional schools and companies may exist that the researchers cannot positively identify. The researchers count as a single school the grades in one or more buildings that are under the supervision of a single principal.
} 
traditional schools in 2002-03. About one-half of 1 percent of all schools nationwide were privately managed schools.

Figure 1: Number of Public Schools Managed by Private Companies from School Year 1998-99 through 2002-03

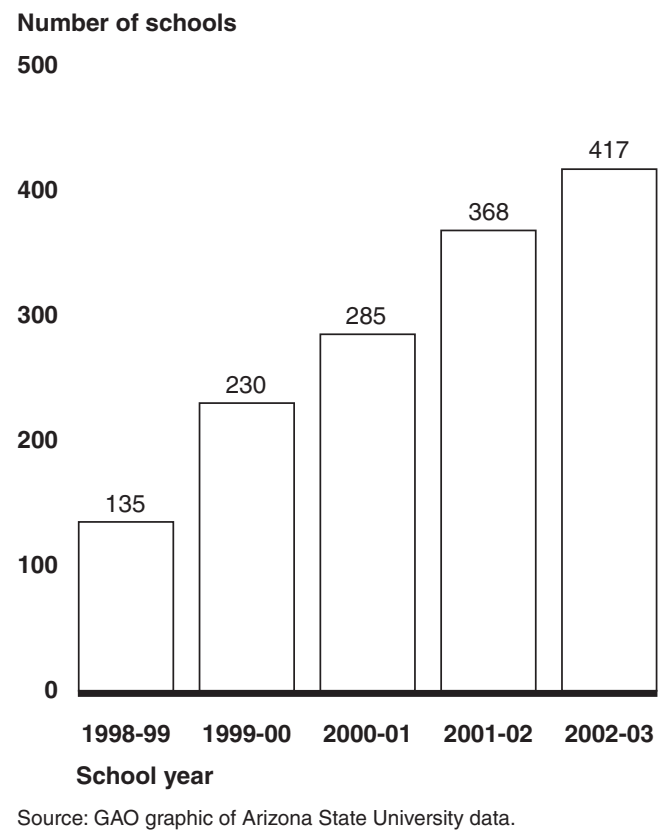

Over the same 5 years, public schools operated by private management companies have also become more geographically widespread, according to data from the Arizona State University study. Figure 2 shows that in school year 1998-99, private management companies operated public schools in 15 states. By school year 2002-03, the companies had schools in 25 states and the District of Columbia, with about 48 percent of the privately managed schools in Arizona and Michigan. Florida, Ohio, and Pennsylvania also had large numbers of schools as indicated by the map in figure 2, which shows the location of public schools operated by private management companies in school year 2002-03. 
Figure 2: Location of Public Schools Operated by Private Management Companies in School Year 2002-03 and Annual Number of States with Such Schools Since 1998-99

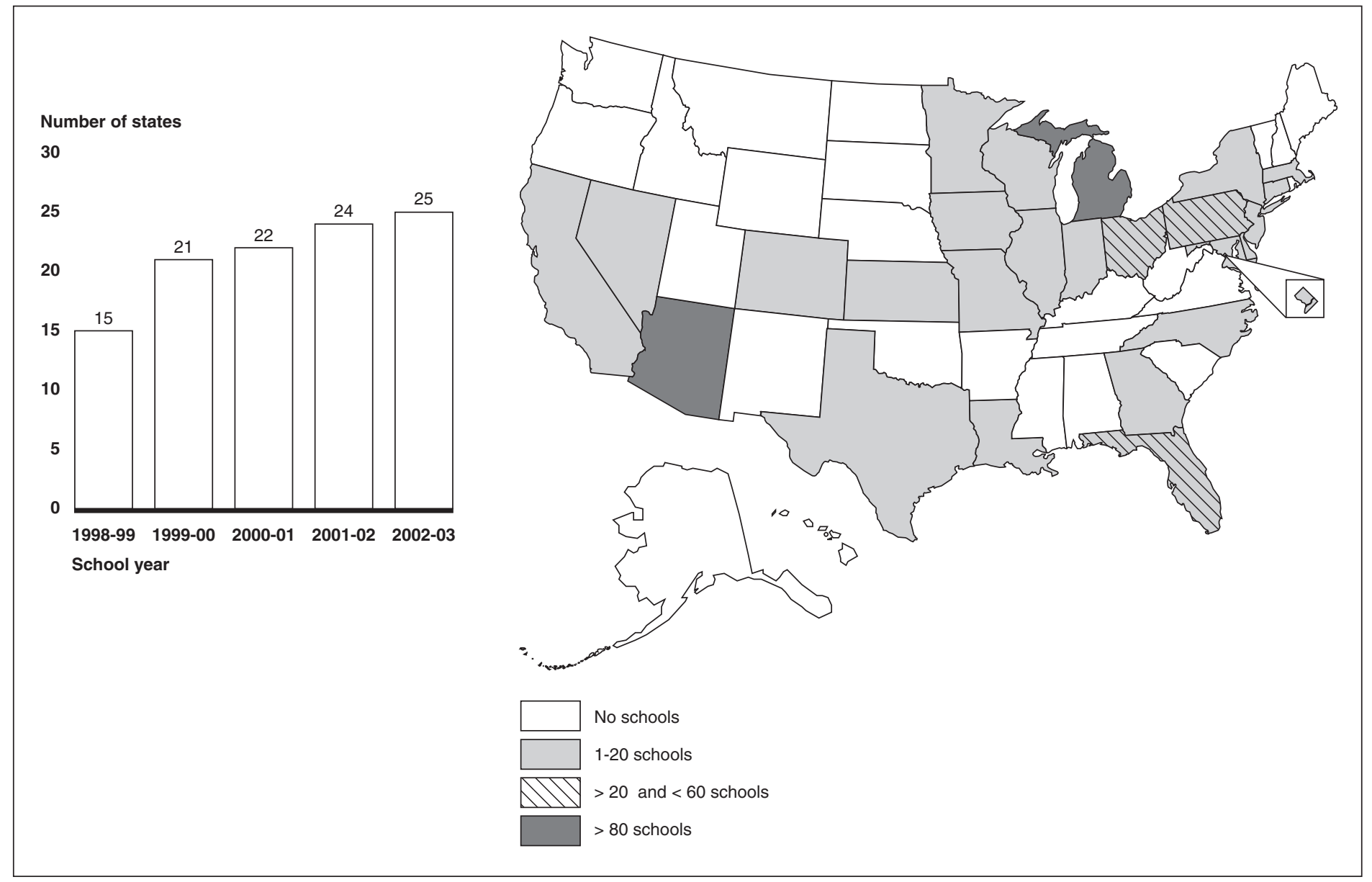

Sources: GAO analysis of Arizona State University data; copyright $\odot$ Corel Corp. All rights reserved (map). 
The number of private management companies identified by the Arizona State University researchers also increased over the same period, but the companies varied greatly in terms of the number of schools they operated. As shown in figure 3, the number of companies increased from 13 in school year 1998-99 to 47 in school year 2002-03. Most of these companies were founded in the decade of the 1990's, but since their founding, some companies have been consolidated or have gone out of business and have been succeeded by newly formed companies. In school year 2002-03, most of the companies were small, operating 15 or fewer schools each. Five medium-sized companies_Chancellor Beacon Academies; The Leona Group; Mosaica Education, Inc.; National Heritage Academies; and White Hat Management-operated from 21 to 44 schools each. The single largest company, Edison Schools, operated 116 schools.

Figure 3: Number of Educational Management Companies from School Year 199899 through 2002-03

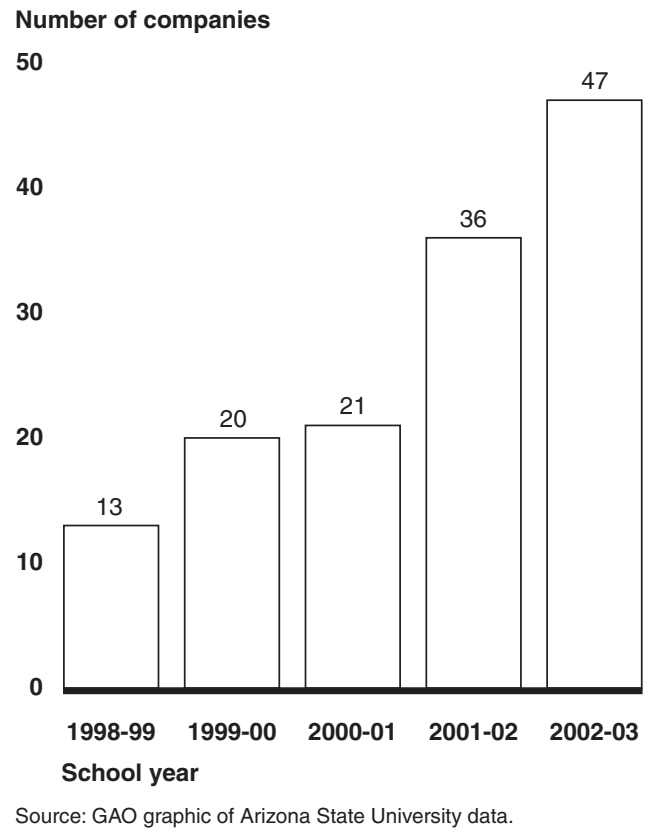


According to the Arizona Sate University report, 43 of the 47 companies operating in school year 2002-03 managed only charter schools. ${ }^{7}$ Charter schools have greater autonomy and decision-making ability in such areas as purchasing and hiring compared with traditional schools that are generally subject to district requirements, including labor agreements. Arizona researchers noted that state charter school laws have provided opportunities for private management that were not present earlier, and Western Michigan University researchers indicated that the growth of private educational management companies occurred soon after charter schools reforms were enacted in that state. They explained that some charter holders started their own private management companies and other charter holders sought the acumen and financial resources of management companies already established in the business. ${ }^{8}$

Individual School Reports Describe Achievement Levels, and Some Company Reports Describe Gains Compared to State or District Averages
Two kinds of reports available to the public — school reports and company reports - described student achievement at privately managed schools relative to national, state, or district averages in school year 2002-03. Referred to as school report cards, the detailed individual school reports generally provided a snapshot of how well students attending the school did in meeting state achievement standards for the year. These report cards were issued by states, school districts, and by some of the larger companies, like the Leona Group for its schools in Michigan. ${ }^{9}$ Often available through the Internet, the report cards for individual schools generally described results of state tests in terms of the proficiency levels or achievement scores for the school overall, by grade level, subject matter, or in some cases, minority group or other subgroup..$^{10}$ Some report cards also provided historical information on the school's performance over several preceding years. School characteristics, such as the size, demographics, staffing, and finances, were included in many cases along with the proficiency levels or achievement scores. Figure 4 is an example

\footnotetext{
${ }^{7}$ Most of the schools managed by two of the other companies were charter schools, but less than one-third of the schools operated by Edison Schools and Victory Schools, Inc., were charter schools.

${ }^{8}$ See Jerry Horn and Gary Miron, An Evaluation of the Michigan Charter School Initiative: Performance, Accountability, and Impact, (Western Michigan University: July 2000).

${ }^{9}$ Individual school reports are also available from GreatSchools.net and from Standard \& Poors for a limited number of schools.

${ }^{10} \mathrm{NCLBA}$ requires that report cards issued by states and districts include this information, but scores for very small subgroups may be withheld to protect the privacy of individual students whose scores might otherwise be inferred.
} 
of the test score section of Colorado's school report card for a hypothetical school. 
Figure 4: Test Score Section of a Report Card for a Hypothetical School in Colorado for School Year 2001-02

\section{StUdent PeRFoRMAnCE}

Colorado students are assessed once a year in order to measure their performance on state academic content standards, using the Colorado Student Assessment Program (CSAP). The chart below shows the results for grades 3 - 5 in the subject areas for reading, writing and math for all students tested.

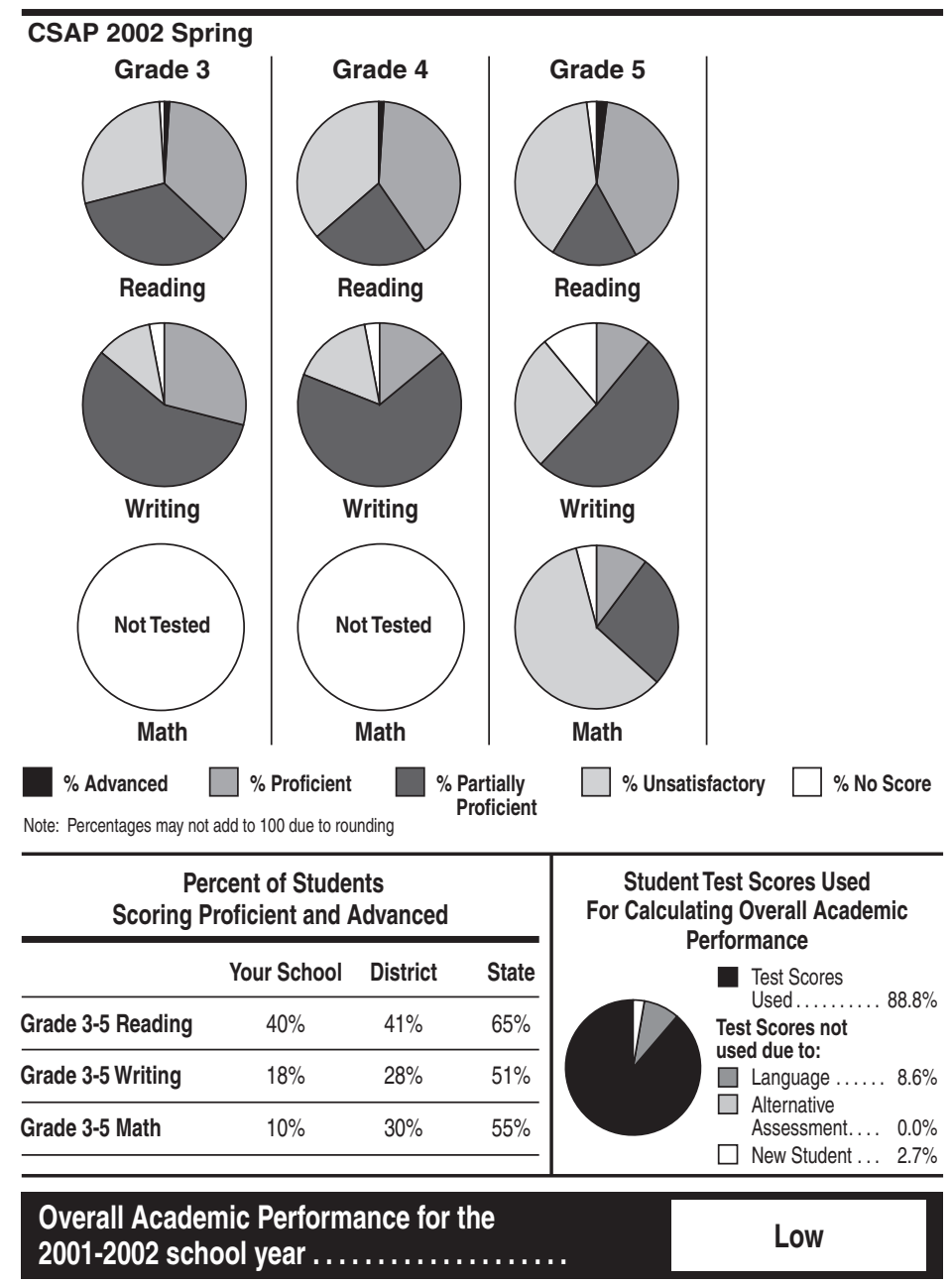

Source: GAO composite developed from Colorado's Department of Education's Web site www.state.co.us/schools.

Note: The Colorado school report cards include an explanation of the factors used to develop the school's overall academic performance in this section. 
As in Colorado, many school report cards compared results to the average in the state or school district, which allowed parents to see how well their children's school was doing-not just in relation to state standards but also in relation to the performance of all other public schools in the state or district. However, these report cards were primarily designed to provide descriptive information for parents and to give an indication of school performance, not to evaluate the relative effectiveness of one school versus another. Report cards usually did not directly compare the performance of one school against other similar schools, and when they did, the comparison schools selected were, by necessity, matched at the school level, rather than the individual student level. ${ }^{11}$ Thus, differences in school performance at any particular grade might be due to differences in the students in that grade, as the reports released by the Leona Group warned, rather than due to factors related to the management or educational strategies of the school. For this reason, report cards, while useful to parents, are not the best source of information if the goal is to evaluate the effectiveness of one school compared with another.

Company reports, a second source of school performance information, tended to provide a summary of how well students at all the company's schools in one or more states were doing over a period of several years. Generally available through the Internet, reports from three companiesMosaica Education, Inc.; the National Heritage Academies; and Edison Schools - emphasized broad patterns, such as gains in achievement test scores or proficiency levels that were averaged across schools, grades, and subjects tested. Our descriptions of the companies' findings are based on their public reports and not on our independent review of their methodologies or conclusions.

Both the Mosaica and National Heritage Academies reports compared student performance to national norms or state averages. The Mosaica Education, Inc., report summarized student gains on tests administered from the fall of school year 1999-2000 through the spring of 2001-02 at its

\footnotetext{
${ }^{11}$ California compares each individual school's rating with the ratings for a set of 100 other schools matched on certain demographic and other characteristics. The comparison schools selected by the state are not required to be within the same geographic area, so that, for example, a school in San Francisco might be matched with a school in San Diego. Colorado compares each individual school's rating with those of other schools in the neighborhood that are selected for their geographic proximity rather than specially matched for demographic and other characteristics.
} 
18 schools in 5 states and the District of Columbia. ${ }^{12}$ According to the report, there was sustained growth in average achievement scores over time, with an increase in the proportion of Mosaica students scoring as well or better than the average student on a nationally normed test and a commensurate decrease in the proportion scoring at or below the 25th percentile. On the basis of these test results, the report stated that about a third of Mosaica's students ranked in the top one-half of the nation's students in school year 2001-02.

The National Heritage Academies report used individual student performance on the state's achievement tests to compare two groups of students attending the company's 22 schools in Michigan in school year 2000-01 - veteran students who took the test at least 2 years after they applied to the school and newcomers who took the test less than 2 years after they applied. ${ }^{13}$ The study found a relationship between time associated with the company's schools and higher performance, with veteran students outperforming newcomers across all subjects and grades tested and also outperforming state averages on 8 out of 10 tests. The report cautioned, however, that such evidence is not proof of causation and that some other factors not accounted for in the study might be responsible for the results.

The Mosaica and National Heritage Academies reports both provided a broad view of overall company performance that, along with school report cards, could give parents more information on which to base their decisions about their children's schooling. However, like school report cards, these two company studies were not designed to more directly assess school effectiveness. Neither company report included comparisons with students at similar traditional schools or addressed the question of whether the patterns of achievement that they identified might also be found in other schools as well.

\footnotetext{
${ }^{12}$ See R. William Cash, Mosaica Education Annual Report: Testing Results 1998-2002 (WestEd: Nov. 2002).

${ }^{13}$ See Gary Wolfram, PhD, Making the (Better) Grade: A Detailed Statistical Analysis of the Effect of National Heritage Academies on Student MEAP Scores, undated, www.heritageacademies.com/hillsdale.pdf, (downloaded June 30, 2003). Because enrollment dates were not available, application dates were used as a proxy for enrollment. Furthermore, because raw scores were not available, the analysis was based on the proficiency levels attained, ranging from 2 possible levels on the writing tests to 4 possible levels on the social studies tests. Other than gender, demographic data also were not available.
} 
Edison's annual report for 2001-02 used a methodology that went further toward assessing school effectiveness than other company reports we examined. ${ }^{14}$ In addition to providing a summary of how well its students were doing over time, Edison compared some of its schools with traditional schools. Generally, the report summarized trends in performance at 94 of Edison's 112 school sites in multiple states over several years, compared to state and district averages. ${ }^{15}$ According to the report, most schools had low levels of achievement at the time Edison assumed management, but achievement levels subsequently increased at most of its school sites. Trends were also provided for several subsets of its schools, including a comparison of 66 of the 94 Edison schools that could be matched with 1,102 traditional schools on two demographic variables. Traditional schools selected as matches were those considered similar in terms of the percentages of students who were AfricanAmerican and/or Hispanic and who were eligible for the free and reducedprice school lunch program, an indicator of low income. ${ }^{16}$ Edison compared the average scores of students in Edison schools with average scores of students in the traditional schools and found that its schools averaged gains that were about 2 percentage points or 3 percentiles higher per year than those of traditional schools and that about 40 of its 66 schools outperformed the traditional schools.

However, the Edison analysis was limited by the fact that it was conducted using aggregated, school-level data and did not control for differences in the individual students being compared. ${ }^{17}$ Edison noted that it has taken steps to strengthen the way it evaluates the progress of its students and schools by commissioning a study by RAND, a nonprofit research organization that has evaluated educational reforms. The study began in

\footnotetext{
${ }^{14}$ See Fifth Annual Report on School Performance: 2001-2002 (Edison: Feb. 2003).

${ }^{15}$ The report explains that 18 schools were excluded due to lack of data for two points in time. For the remaining 94 schools, trends were calculated from various beginning dates through 2001-02. The beginning dates varied by school, depending on when Edison assumed management, and ranged from school year 1995-1996 to school year 2000-01.

${ }^{16}$ For the comparison, all traditional schools in a district were considered similar and included if their enrollment was within 10 percentage points of the Edison school on both student characteristics. If no traditional schools were that close, then they were considered similar and included if their enrollment was within 10 percentage points on one characteristic and 30 percentage points on the other characteristic.

${ }^{17}$ An Edison official told GAO that the company did not have access to individual data on students at traditional public schools used for the comparison, so it was not able to conduct such an analysis.
} 
2000 and is scheduled for release in the summer of 2004 . Where possible, RAND plans to compare the scores of individual Edison students to those of traditional public school students with similar characteristics.

No Consistent Pattern
of Differences in
Scores on State Tests
Found between
Public Schools
Managed by Private
Companies and
Comparable,
Traditional
Elementary Schools

No Consistent Pattern of Differences in Scores on State Tests Found between Scores on State Tests Were Higher in Privately Managed Schools in Denver and San Francisco
Differences in student performance on state assessments between privately managed public schools and comparable, traditional public schools varied by metropolitan areas for the grade levels in our study. ${ }^{18}$ Average student scores were significantly higher in both reading and math for fifth graders in 2 privately managed schools, 1 in Denver and 1 in San Francisco, compared with similar traditional public schools, as were gains over time when we examined a previous year's scores for these students. However, fourth grade scores in the privately managed school in Cleveland and fifth grade scores at 2 privately managed schools in St. Paul were significantly lower compared with scores in the similar traditional schools. In Detroit, average fifth grade reading scores were significantly lower in 6 of the 8 privately managed schools, and math scores were lower in all but 1 privately managed school. No significant differences in reading or math scores were found between the privately managed school and comparison schools in Phoenix.
Average scores on state tests for fifth grade students attending privately managed schools in Denver and San Francisco were significantly higher compared with students attending similar, traditional public schools. Table 2 shows the characteristics used in matching privately managed and traditional schools in Denver and San Francisco and how the selected schools compared on these characteristics. ${ }^{19}$ As shown, schools generally had high proportions of minority and low-income students (as measured by free/reduced-lunch program eligibility) and students with limited English proficiency (LEP). For our test score analyses, we were able to

\footnotetext{
${ }^{18}$ The word significant is used in this section to refer to statistical significance. Differences discussed are significant at the 95-percent confidence level using ordinary least squares regression models. Due to concerns about certain assumptions inherent in these models, we also ran models using robust estimation procedures to calculate standard errors. For all models, the robust procedures yielded almost identical results to those of the ordinary least squares. See appendix I for further details.

${ }^{19}$ For brevity, we show percent minority in this and similar tables. However, our matching process actually used various categories of race/ethnicity, depending on the data available for the site, rather than a single minority category. See appendix II for the exact categories used.
} 
obtain data on characteristics shown in table 2 for individual students in our study, as well as data on student mobility. ${ }^{20}$ We used these data in the test score analyses to further control for student differences in the grade level we studied. (See app. II, where tables 5 and 6 show detailed results of these analyses.)

Table 2: School Characteristics of the Privately Managed Schools and Comparison Schools in Denver and San Francisco

\begin{tabular}{|c|c|c|c|c|c|c|}
\hline City & $\begin{array}{l}\text { Privately managed/ } \\
\text { traditional }\end{array}$ & Enrollment & $\begin{array}{l}\text { Percent free and } \\
\text { reduced lunch }\end{array}$ & $\begin{array}{r}\text { Percent special } \\
\text { education }\end{array}$ & Percent LEP & $\begin{array}{l}\text { Percent } \\
\text { minority }\end{array}$ \\
\hline Denver & Privately managed & 665 & 76 & 8 & 27 & 95 \\
\hline Denver & Traditional & 645 & 77 & 4 & 40 & 95 \\
\hline Denver & Traditional & 638 & 52 & 7 & 25 & 95 \\
\hline Denver & Traditional & 403 & 80 & 8 & 52 & 96 \\
\hline Denver & Traditional & 394 & 76 & 15 & 23 & 77 \\
\hline San Francisco & Privately managed & 506 & 68 & 4 & 40 & 95 \\
\hline San Francisco & Traditional & 474 & 96 & 9 & 51 & 97 \\
\hline San Francisco & Traditional & 525 & 81 & 10 & 33 & 96 \\
\hline
\end{tabular}

Source: Common Core of Data school year 2000-01 and school districts.

As shown in figure 5, in Denver the average reading score of 572 for fifth grade students in the privately managed public school is higher, compared with the average of 557 for students in similar traditional public schools. The average math score of 467 at the privately managed school is also higher than the 440 average score in the comparison traditional schools. For both reading and math, differences in scores remained significantly higher after we controlled for factors representing differences in the student populations.

\footnotetext{
${ }^{20}$ In these analyses, a student is considered mobile if he or she did not attend the same school in the prior year.
} 
Figure 5: Fifth Grade Reading Scores for the Privately Managed School and Comparison Schools in Denver on the Colorado Student Assessment Program

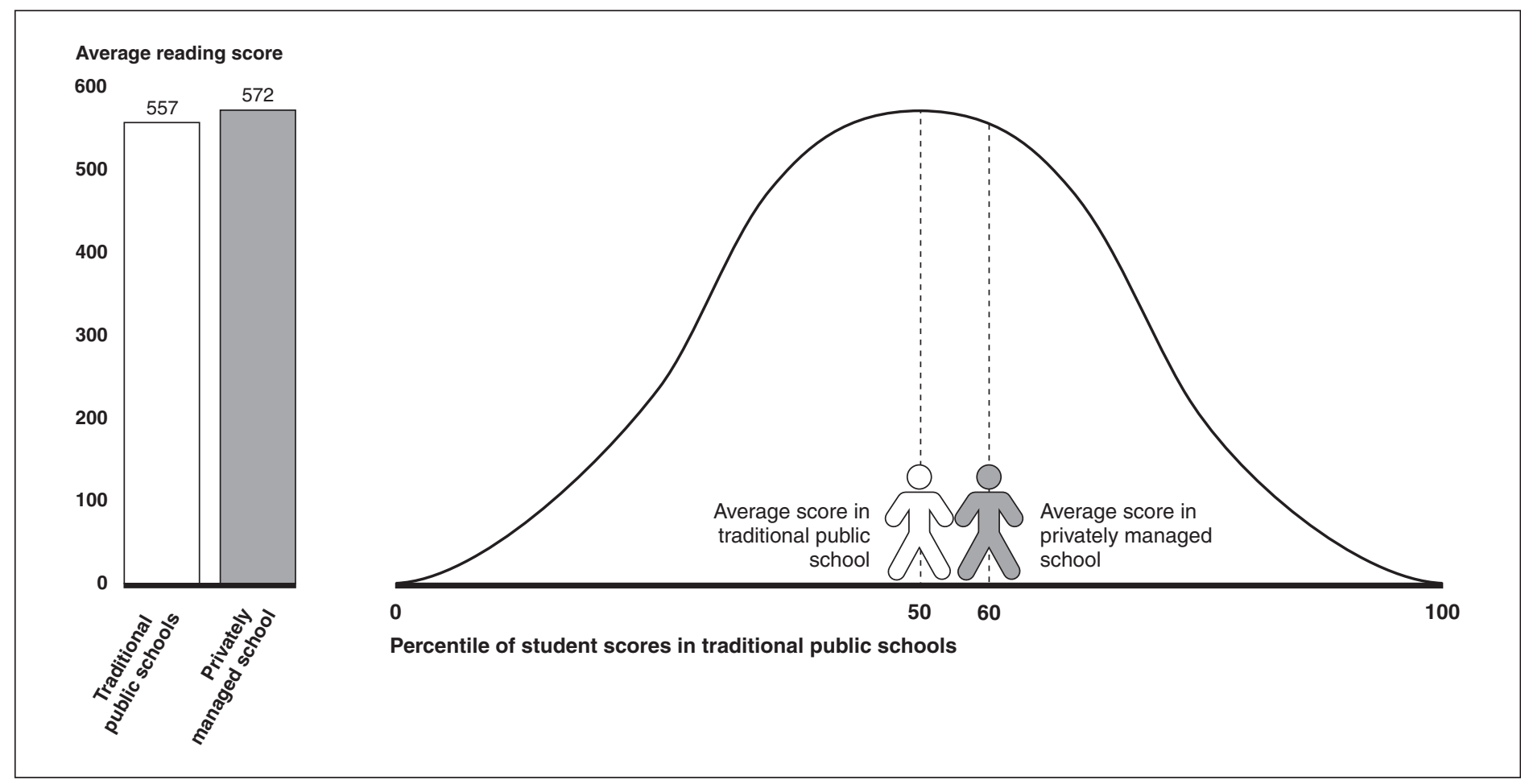

Source: GAO data analysis.

Note: Percentiles are derived from analyses that control for differences in student characteristics.

Figure 5 also shows the difference in reading performance, controlling for other factors, between the typical student at the privately managed school and the average student at the same grade level in the similar traditional schools in Denver. The bell curve represents the distribution of combined student scores in the traditional schools, with the lighter figure representing the student scoring at about the 50th percentile. The shaded figure represents the average student from the privately managed school. Although this student's score is at about the 50th percentile in the privately managed school, the same score would place him or her at about the 60 th percentile when compared against the scores of students in the traditional schools. The difference in math scores suggests a similar outcome - that is, the average student in the privately managed school 
would score at about the 60th percentile in the comparison traditional schools. $^{21}$

In San Francisco, fifth grade reading scores averaged 636 for students in the privately managed school and 627 for students in the comparison traditional schools. Performance in mathematics of 640 was also higher for fifth grade students at the privately managed school, compared with 623 for students in the similar traditional schools. (See fig. 6.) As in Denver, these differences were significant when controlling for other factors. This analysis suggests that an average student in the privately managed school would likely exceed about 60 percent of students in the traditional comparison schools in reading and about 65 percent of those students in math.

${ }^{21}$ See appendix I for a further discussion of this effect size illustration and additional analyses comparing the privately managed school in Denver with different groupings of the comparison traditional schools. 
Figure 6: Fifth Grade Reading and Math Scores for the Privately Managed School and Comparison Schools in San Francisco on the Stanford-9 Achievement Test

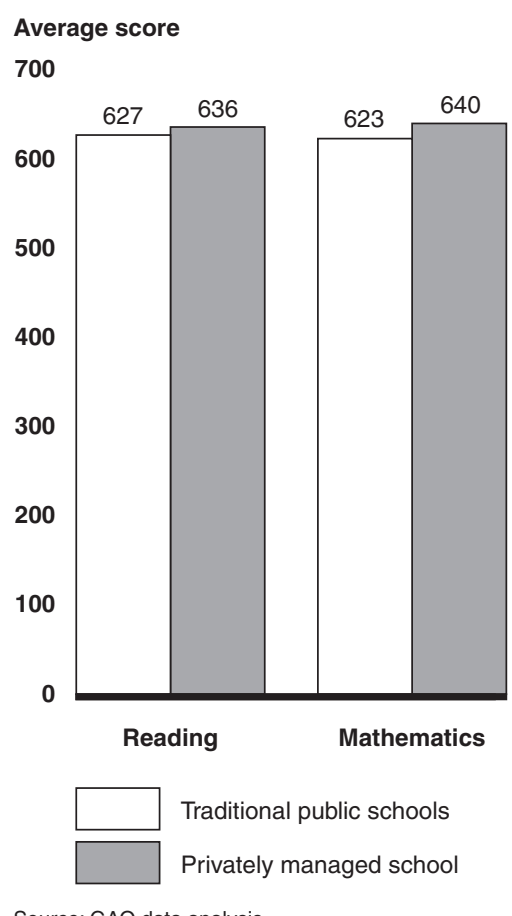

Source: GAO data analysis.

In both Denver and San Francisco, we were able to examine student performance over time, and our findings of achievement over time were similar to the findings described above. Students attending the privately managed schools showed significantly greater gains over time than the students in the comparison traditional schools. Specifically, fifth-grader students in our study who had attended their privately managed schools since the third grade demonstrated significantly higher achievement gains between grades 3 and 5 than did such students in the traditional comparison schools. ${ }^{22}$

\footnotetext{
${ }^{22}$ Third grade scores were available only for reading in Denver; in San Francisco both reading and mathematics were examined.
} 


\section{Scores on State Tests Were Lower in Privately Managed Schools in Cleveland and St. Paul}

Average scores on state tests for fourth grade students attending privately managed schools in Cleveland and fifth grade students attending privately managed schools in St. Paul were significantly lower compared with scores of students attending similar traditional public schools. ${ }^{23}$ One privately managed school in Cleveland and 2 privately managed schools in St. Paul were examined, and as in Denver and San Francisco, the schools in our study from these cities were high minority and low-income schools. Table 3 shows the characteristics used to match schools in Cleveland and St. Paul and how the schools selected compared on these characteristics. For our test score analyses in Cleveland, we were able to obtain data on characteristics shown in table 3 for individual students in our study, as well as data on student mobility. ${ }^{24}$ In St. Paul, we obtained data on all characteristics shown in table 3 for individual students, except special education. ${ }^{25}$ In addition, we were able to obtain data on limited English proficiency. We used these data in the test score analyses for both cities to further control for student differences in the grade level we studied. (See app. II, where tables 7, 8, and 9 show detailed results of these analyses.)

\footnotetext{
${ }^{23}$ See appendix I for a discussion of additional analyses comparing the privately managed school in Cleveland and St. Paul with different groupings of the comparison traditional schools.

${ }^{24}$ In Cleveland, no students in our study were designated as limited in English proficiency.

${ }^{25}$ The special education data we received on individual students in St. Paul were not complete and thus were not used in our analyses of individual test scores.
} 
Table 3: School Characteristics of the Privately Managed Schools and Comparison Schools in Cleveland and St. Paul

\begin{tabular}{|c|c|c|c|c|c|}
\hline City & $\begin{array}{l}\text { Privately managed/ } \\
\text { traditional }\end{array}$ & Enrollment & $\begin{array}{l}\text { Percent free and } \\
\text { reduced lunch }\end{array}$ & $\begin{array}{r}\text { Percent special } \\
\text { education }\end{array}$ & $\begin{array}{l}\text { Percent } \\
\text { minority }\end{array}$ \\
\hline Cleveland & Privately managed & 411 & 77 & 4 & 100 \\
\hline Cleveland & Traditional & 422 & 80 & 10 & 100 \\
\hline Cleveland & Traditional & 496 & 88 & 8 & 99 \\
\hline Cleveland & Traditional & 352 & 77 & 16 & 99 \\
\hline Cleveland & Traditional & 561 & 99 & 8 & 99 \\
\hline St. Paul & Privately managed & 116 & 70 & 12 & 51 \\
\hline St. Paul & Traditional & 386 & 46 & 12 & 43 \\
\hline St. Paul & Traditional & 484 & 48 & 12 & 50 \\
\hline St. Paul & Traditional & 223 & 71 & 9 & 72 \\
\hline St. Paul & Traditional & 348 & 59 & 10 & 69 \\
\hline St. Paul & Privately managed & 126 & 71 & 14 & 72 \\
\hline St. Paul & Traditional & 313 & 76 & 16 & 82 \\
\hline St. Paul & Traditional & 223 & 71 & 9 & 72 \\
\hline St. Paul & Traditional & 438 & 64 & 13 & 76 \\
\hline St. Paul & Traditional & 524 & 68 & 17 & 61 \\
\hline
\end{tabular}

Source: Common Core of Data school year 2000-01 and school districts.

Figure 7 shows average reading scores for the privately managed school in Cleveland and its set of comparable schools. The average scores were significantly lower for students attending the privately managed school in both reading and math for the school years examined after controlling for other factors. The magnitude of the difference in reading scores is shown in the same figure 7 . As can be seen in the figure, the score of the average student in the fifth grade in the privately managed school falls at about the 20th percentile when compared with student scores in the comparison traditional schools. Similarly, the difference in math scores implies that the average student in the privately managed school would score at about the 20th percentile in the traditional comparison schools. 
Figure 7: Fourth Grade Reading Scores for the Privately Managed School and Comparison Schools in Cleveland on the Ohio Proficiency Test

Average reading score

250
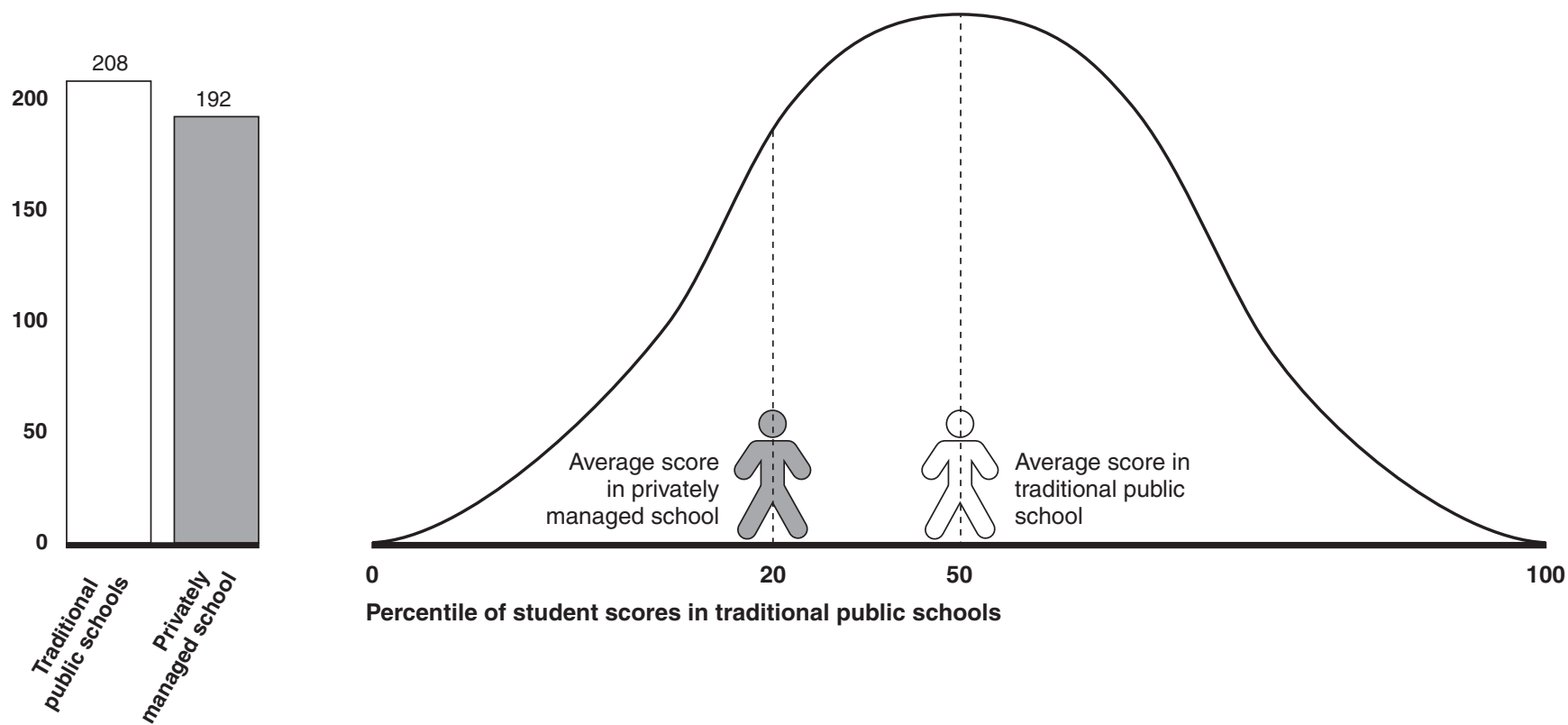

Source: GAO data analysis

Note: Percentiles are derived from analyses that control for differences in student characteristics.

In St. Paul, we studied 2 privately managed schools (labeled school A and school B in figure 8) and used a different set of comparison traditional schools for each privately managed school. The average scores in both reading and math were significantly lower for students at both privately managed schools studied compared with similar traditional schools. 
Figure 8: Fifth Grade Reading and Math Scores for the Privately Managed Schools and Comparison Schools in St. Paul on the Minnesota Comprehensive Assessment Program

School A comparisons

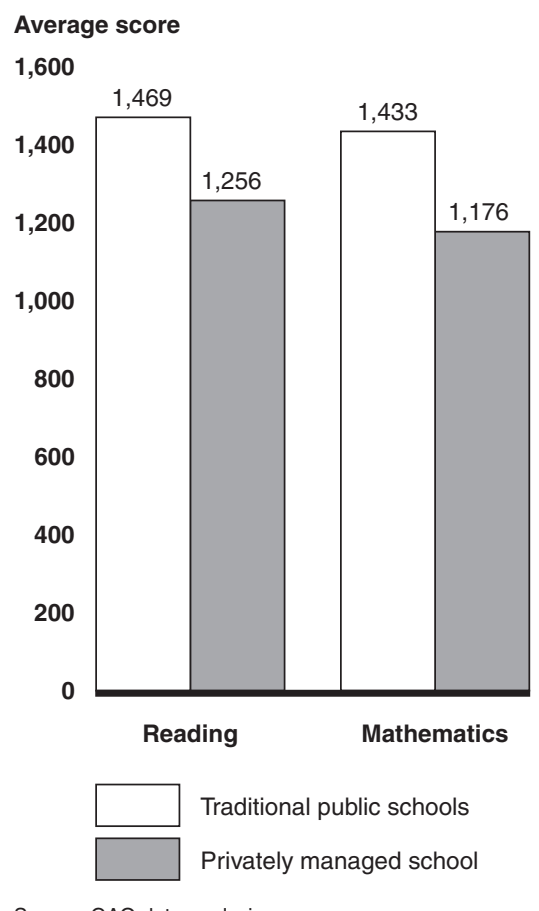

School B comparisons

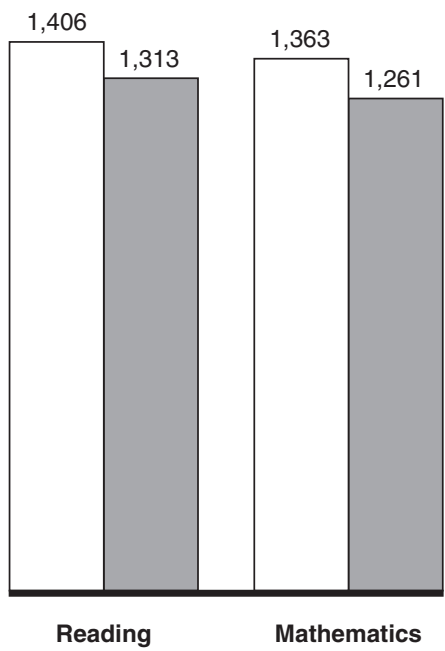

The differences for the first privately managed school suggest that an average student at that school would score at about the 30th percentile in reading and the 20 th percentile in math if attending the comparison traditional schools. The differences in scores at the second privately managed school imply that the score of an average student would be at about the 30th percentile in the comparison traditional schools in both reading and math. 
Scores on State Tests in Privately Managed Schools Varied in Detroit and Were Similar to Traditional Schools in Phoenix
Average scores for fourth grade students in Detroit varied, but tended to be lower in both reading and math for students attending privately managed schools than for students attending similar traditional schools. ${ }^{26}$ As in other locations, student populations in schools we studied in Detroit tended to be minority and low income. (See app. III for other school characteristics.) Except for race/ethnicity, we did not use individual student demographic data in the Detroit test score analyses because the demographic data we received on individual students did not appear to be accurate. In spite of these missing data, we believe the analyses provide useful information, given the degree of similarity among the matched schools.

As shown in figure 9 , reading scores were significantly lower for students in six of the privately managed schools compared with students in similar traditional schools in Detroit. The size of these differences generally suggested that an average student attending the privately managed schools would score at about the 30th percentile in the similar traditional schools. In one comparison (labeled $\mathrm{C}$ in fig. 9), reading scores were significantly higher in the privately managed school compared with similar traditional schools. Students at this privately managed school would likely perform at about the 70th percentile in the traditional schools. For one other privately managed school (comparison B), differences in scores were not significantly different.

\footnotetext{
${ }^{26}$ For Detroit schools, because of difficulties obtaining data and changes in the test, we analyzed reading and math test scores for 1 school year-2001-02.
} 
Figure 9: Fourth Grade Reading Scores for Privately Managed and Comparison Schools in Detroit on the Michigan Education Assessment Program

Average reading score

400

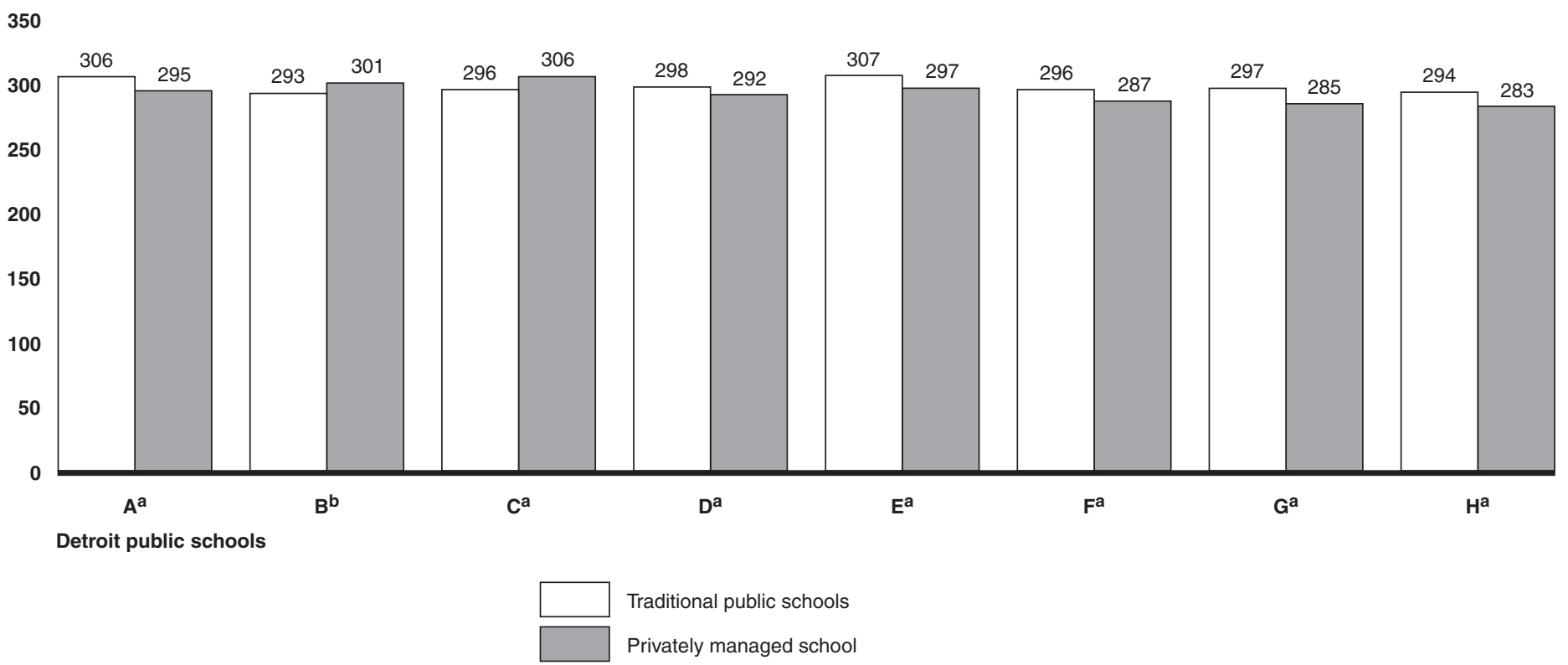

Source: GAO data analysis.

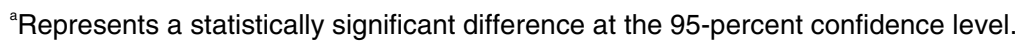

${ }^{b}$ Not statistically significant at the 95-percent confidence level but approaches significance $(p<.06)$.

Note : There are two parts to this reading exam, story section and information section. The reported reading scores are an average of the two sections and are only for the 2002 school year.

Math scores followed a similar pattern, with student scores significantly lower at 7 of the 8 privately managed schools when compared with similar traditional schools. Scores for average students in the privately managed school would range from about the 15th percentile to about the 35th percentile in the traditional schools, depending on the particular set of schools compared. In the one higher-performing privately managed school (comparison B in fig. 10), an average student in this privately managed school would score at the 70th percentile in similar traditional schools. 
Figure 10. Fourth Grade Math Scores for Privately Managed and Comparison Schools in Detroit on the Michigan Education Assessment Program

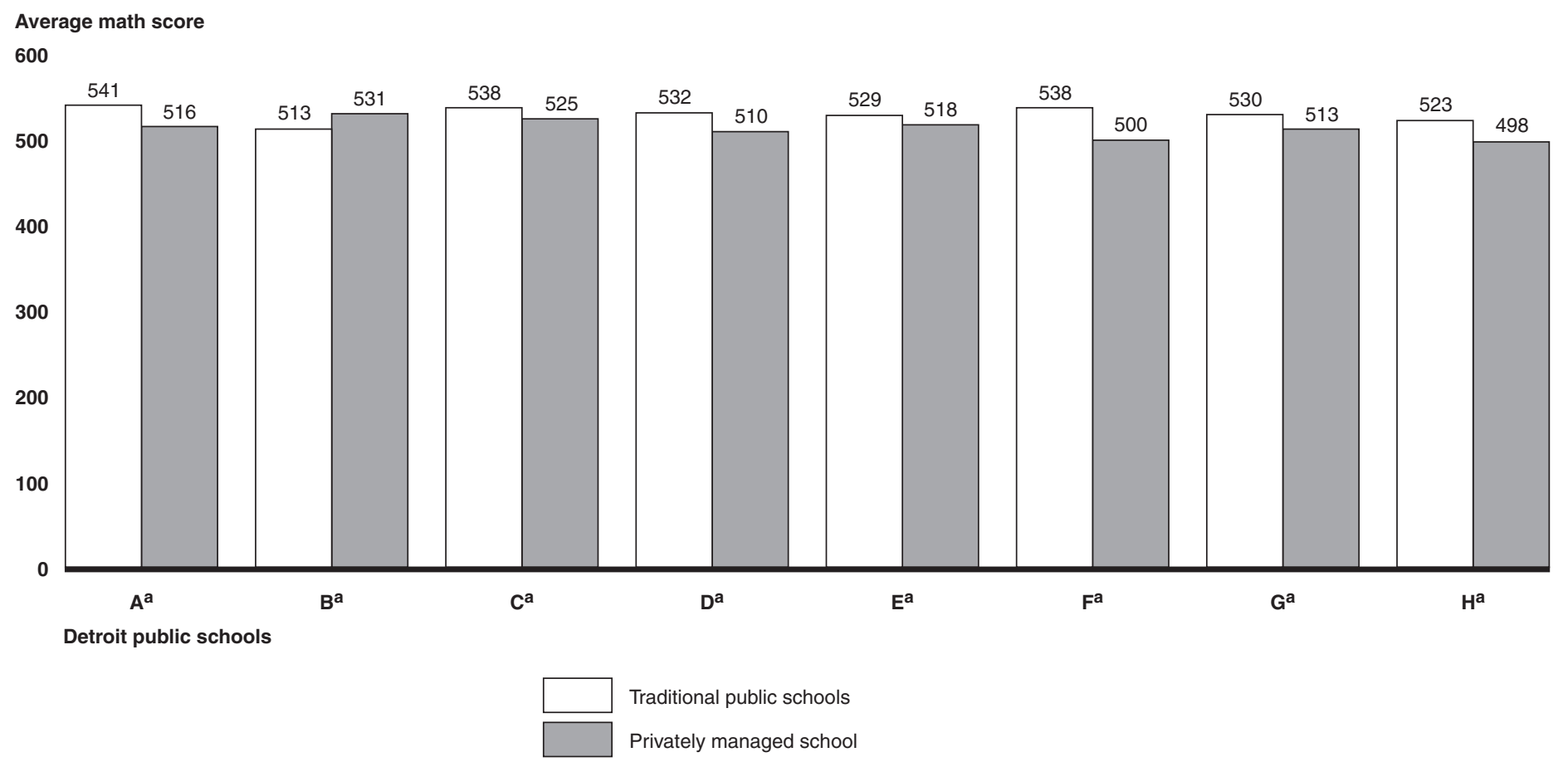

Source: GAO data analysis.

${ }^{a}$ Represents a statistically significant difference at the 95-percent confidence level.

In Phoenix, scores of fifth grade students at the privately managed school did not differ significantly from scores at similar traditional schools. As in the other locations studied, both the privately managed and similar traditional schools had high percentages of minority and low-income students. Table 4 shows the characteristics of the schools in our study in Phoenix. For test score analyses, we were able to obtain reliable data for minority status for individual students. Additionally, we obtained reliable data on student mobility, and these were included in our analysis. Data on special education and limited English proficiency for individual students were not believed to be accurate and were not included. Individual student data on free and reduced-lunch eligibility were not available. 
Table 4: School Characteristics of the Privately Managed School and Comparison Schools in Phoenix

\begin{tabular}{llrrrrr}
\hline City & $\begin{array}{l}\text { Privately managed/ } \\
\text { traditional }\end{array}$ & Enrollment & $\begin{array}{r}\text { Percent free and } \\
\text { reduced lunch }\end{array}$ & $\begin{array}{r}\text { Percent special } \\
\text { education }\end{array}$ & $\begin{array}{r}\text { Percent LEP } \\
\text { Percent } \\
\text { minority }\end{array}$ \\
\hline Phoenix & Privately managed & 1,066 & 96 & 25 & 50 \\
\hline Phoenix & Traditional & 913 & 81 & 49 & 48 \\
\hline Phoenix & Traditional & 682 & 97 & 15 & 48 \\
\hline Phoenix & Traditional & 544 & 92 & 95 & 39 \\
\hline Phoenix & Traditional & 1,138 & 97 & 95 \\
\hline
\end{tabular}

Source: Common Core of Data school year 2000-01 and state education department.

Figure 11 shows average student scores for reading and math in the privately managed school and in the comparison traditional schools for Phoenix. Scores were not significantly different in either reading or math. We also analyzed changes in reading and math scores between third and fifth grade for those students who had tested in the same school in both years. Again, we found no significant difference between students attending the privately managed school and those attending traditional schools. 
Figure 11: Fifth Grade Reading and Math Scores for the Privately Managed School and Comparison Schools in Phoenix

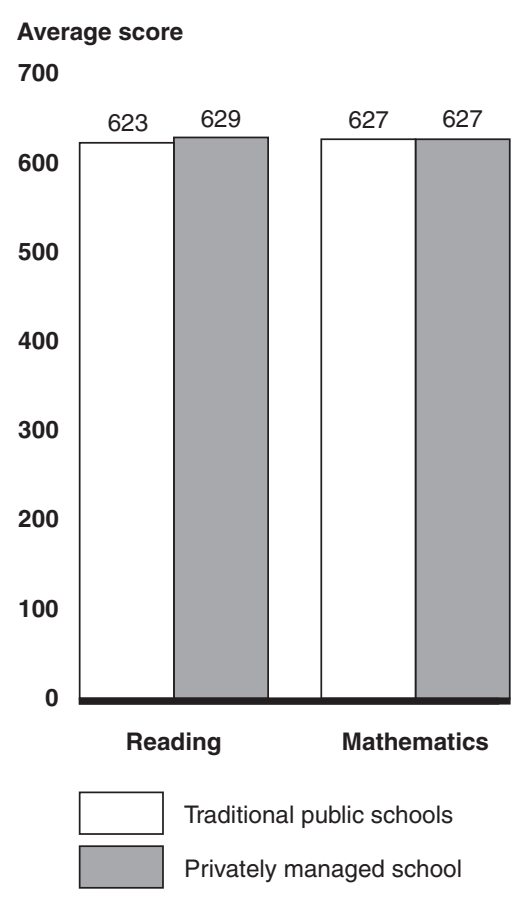

Source: GAO data analysis.

Concluding Observations
As opportunities increase for parents to exercise choice in the public education arena, information on school performance, such as that found in school report cards produced by many states, becomes more important. Such information can be useful to parents in making school choices by providing a variety of information about schools, including how they are performing in terms of students meeting state achievement standards or relative to statewide averages.

However, educators and policymakers often want to know not only how well schools are performing but also the factors that contribute to their high or low performance so that successful strategies can be emulated. Answering this kind of evaluative question requires a different kind of methodology and more complex analyses to isolate the effects of the particular strategies of interest-educational practices, management techniques, and so on - from the many other factors that could affect student achievement. Although not a comprehensive impact evaluation, our study investigates the effect of school management by comparing 
traditional and privately managed schools and by controlling for differences in the characteristics of students attending the schools. In this way, our study provides a different type of information than that typically found in school report cards.

While our study explores the role of school management, it has certain important limitations, as discussed earlier and in appendix I. Among these are data issues commonly encountered by educational researchers, for instance, lack of test score data for successive years and unreliable demographic data for individual students in some sites. However, with the implementation of NCLBA, more rigorous studies should be possible, as annual testing of all grades is phased in and with expected improvements in the quality of demographic data resulting from requirements to report progress for various subpopulations of students, based on such characteristics as race and low-income status.

Finally, our mixed results may be evidence of the complexity of the factor under study. Our study analyzed differences between 2 categories of schools, grouped by whether they were traditional, district-managed schools or managed by a private company. However, these schools may have differed in other ways not included in our study-for example curricula, staff composition and qualifications, and funding levels-and these factors may also have affected student achievement. Any of these factors or combination of factors could account for the differences we found or may have masked the effects of differences we otherwise would have found. review and comment. Education's Executive Secretariat confirmed that department officials had reviewed the draft and had no comments. 
We are sending a copy of this report to the Secretary of Education, relevant congressional committees, appropriate parties associated with schools in the study, and other interested parties. We will make copies available to others upon request. In addition, the report will be available at no charge on GAO's Web site at http://www.gao.gov.

If you or your staff have any questions about this report, please call me at (202) 512-7215. See appendix IV for other staff acknowledgments.

Sincerely yours,

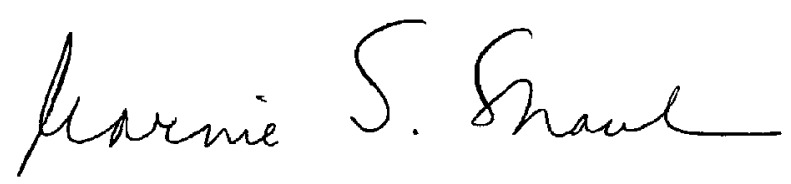

Marnie S. Shaul, Director

Education, Workforce, and

Income Security Issues 


\section{Appendix I: Scope and Methodology}

To compare achievement of public elementary schools in large cities operated by private management companies with similar traditional public schools, we analyzed individual student scores on state assessments in reading and mathematics. We matched each privately managed public school with 2 to 4 traditional public schools located in the same city that were similar in terms of size, grade span, and student characteristics. To confirm the reasonableness of the matches, we spoke with principals in all of the privately managed schools in our study and visited most of the schools. We also spoke with principals and visited many of the traditional schools selected. For selected grade levels, we compared the individual student scores of students attending the privately managed schools with those of students in the similar traditional public schools. We also compared changes in individual student performance over time where such data were available. This appendix describes the scope and school selection, outcome measures and analytic methods, and the limitations of the analysis.

\section{Scope and School Selection}

Using available public information, ${ }^{1}$ we attempted to identify all privately managed public elementary schools in large urban areas that had been in continuous operation by the same management company since the 1998-99 school year. ${ }^{2}$ We defined a large urban area for this study as a central city with a population of at least 400,000 in a standard metropolitan statistical area with a population of at least 2,000,000. We identified 17 public elementary schools managed by private companies meeting these criteria. ${ }^{3}$ The 17 schools were located in Cleveland, Ohio; Denver, Colorado; Detroit, Michigan; Phoenix, Arizona; St. Paul, Minnesota; and San Francisco, California.

\footnotetext{
${ }^{1}$ The most comprehensive source we found for this information was a report done by Arizona State University. We selectively verified data in this report with other sources, such as compilations done for the Center for Education Reform and the National Association of Charter School Authorizers.

${ }^{2}$ If an elementary school managed by a private company also included middle or high school grades, the school was retained in the study if other selection criteria were met.

${ }^{3}$ We identified schools in Washington, D.C., and Miami, Florida, that met our selection criteria. We did not include Miami in this study because we previously reported the results of a study of the privately managed school at this site. See U.S. General Accounting Office, Public Schools: Insufficient Research to Determine Effectiveness of Selected Private Education Companies, GAO-03-11. (Washington, D.C.: Oct. 29, 2002). We did not include Washington, D.C., because we were concerned about obtaining reliable data.
} 
We matched each of these privately managed schools with 2-4 similar traditional public schools in the district where the privately managed school was located. ${ }^{4}$ To select similar traditional public schools, we employed a "total deviation" score procedure. For each public elementary school in the defined public school district and the privately managed school, we determined the following school characteristics: (1) racial and ethnic percentages, ${ }^{5}(2)$ percent special education, (3) percent eligible for free and reduced lunch, (4) percent limited-English proficient, ${ }^{6}$ and (5) student enrollment. We calculated z-scores (the statistic that indicates how far and in what direction the value deviates from its distribution's mean, expressed in units of its distribution's standard deviation) for each characteristic, and then calculated the absolute value of the difference between the z-score of the privately managed school and the z-score of each traditional public school on that characteristic. For each school, we summed the absolute difference in z-scores into a total deviation score. The total deviation score represents the sum of the differences between the privately managed public school and the candidate traditional public schools.

Traditional public schools were considered a close match if the total deviation score divided by the number of characteristics for which we computed z-scores was less than or equal to 1.0. A score less than or equal to 1.0 indicates that the traditional school did not deviate from the privately managed school by more than 1 standard deviation when averaging across all variables considered in the match. For example, if 8 variables were used to calculate the total deviation score and the total deviation score was 7.8 , the amount that the candidate school deviated from the privately managed school would be, on average, less than 1 standard deviation. All comparison schools selected for our analyses met this criterion for a close match.

\footnotetext{
${ }^{4}$ In Phoenix, the Phoenix Unified High School District was used as the district demarcation for drawing matching traditional public schools.

${ }^{5}$ The specific matching variables varied from city to city. If students in a given racial or ethnic group comprised less than 10 percent of the student population in the privately managed school and if students in that racial or ethnic group comprised less than 10 percent of the student population for the other schools in the district, excluding outliers, we excluded that racial or ethnic group as a specific matching variable.

${ }^{6}$ We sought, but were not able to obtain for use in the matching process, data on percentage of students with limited English proficiency for schools in St. Paul and Detroit.
} 
After mathematically selecting close matches, we consulted with public school district officials about the schools selected. ${ }^{7}$ These considerations led to adjustments to our final selection of matches as follows. In St. Paul, traditional public schools closely matching the privately managed schools included magnet schools and neighborhood, that is, attendance-zone, schools. The two "best" matching magnet schools and the two "best" neighborhood schools were selected as matches for the analysis. Similarly in Cleveland, traditional public schools closely matching the privately managed schools included former magnet schools and traditional neighborhood schools. For balance in matching, the two "best" matching former magnet schools and two "best" matching neighborhood schools were selected as matches for the analysis. In Denver, the five closest matching schools were all located in a distinct neighborhood, geographically distant from the privately managed school. In consultation with local school district personnel, the two "best" matching schools from this area and the two "best" matching schools from outside this area were selected for the analysis. In San Francisco, one of the three traditional school matches was discarded because it had a special teacher training program, resulting in only two matches with the privately managed school. In Detroit, the best three matching traditional schools were selected except in one instance where one of the matching schools was discarded because a subsequent site visit determined that the school had selection criteria for attendance based upon prior achievement. In Phoenix, there were 21 elementary school districts located in the city, and 13 of these districts comprise the Unified Phoenix High School District. Since the privately managed schools were located within the Unified Phoenix High School District, we selected matches from among the 13 school districts in the Unified Phoenix High School District using the "best" matching school of each elementary school district as a pool from which we selected the best four matches, each from a different school district.

Two privately managed schools in Phoenix and one privately managed school in Cleveland were dropped from the analysis because no matching traditional schools were found using our methodology. This resulted in a total of 14 privately managed schools included in the study, 8 of which were located in Detroit. Schools selected were managed by Designs for Learning, Inc.; Edison Schools; The Leona Group; Mosaica Education, Inc.; Schoolhouse; and White Hat Management.

${ }^{7}$ Phoenix had multiple school districts, so we consulted with state officials. 
Measures and Analytic Methods
We used student reading and math scale scores on routinely administered state assessments as measures of academic achievement. At the time of our study, the most recent data available were for school year 2001-2002. Test scores and student characteristic data were obtained from either the school district or state education agency. We used a variety of approaches to verify the accuracy of these data. In most cases, we verified data by comparing a sample of the data received against school records examined at the school site. In Detroit, data verification indicated student lowincome, special education, and mobility data provided by the state were unreliable, and we decided not to use these data in our final analyses. In Phoenix, data verification indicated that student limited-English proficiency and special education data provided by the state for the privately managed school were unreliable and this was confirmed with diagnostic analysis. Therefore, we were unable to include these control variables in our final analyses.

For each privately managed school and its set of matched, comparison schools, we selected the highest elementary grade for which test scores were available. We collected test score information for 2 school years, 2000-01 and 2001-02, except in Detroit where only 2001-02 scores were used due to difficulties obtaining data and changes in the test given. For each site, we compared reading and math student scores in the privately managed school(s) with the scores of same-grade students in the set of matched, comparison schools. The scores for the 2000-01 and 2001-02 school years were combined in the analysis. ${ }^{8}$ In addition, in three locations where testing occurred more frequently, Denver, Phoenix, and San Francisco, we obtained third grade scores for students who had taken the state assessment in the same school and examined the difference in scores over time.

For each site, we conducted multivariate ordinary least squares (OLS) regression analysis to quantify differences in student achievement while controlling for school type and student characteristics. Specific independent variables included in the regression model were as follows:

- School type, with the traditional public school being given a value of 1 and the privately managed school a value of 0 .

${ }^{8}$ Diagnostic analysis determined that school year was not related to achievement scores in all sites except for reading scores in San Francisco. 
- Mobility, with a value of 1 given to students not attending for 2 years the same school at which he or she took the state assessment.

- Limited English proficiency (LEP), with a value of 1 given if the child was designated as limited-English proficient. ${ }^{9}$

- Special education, with a value of 1 given if the student was enrolled in special education. ${ }^{10}$

- Low-income, with a value of 1 indicating the student was eligible for free or reduced lunch. ${ }^{11}$

- Race and ethnicity, with a value of 1 given for the child's appropriate minority racial/ethnic identity. Each child was placed in only one racial category, and the number of racial categories used varied from place to place. When numbers for a particular racial group in a city were small, they were combined collectively as "other minority." (Specific racial and ethnic identities employed in each city are set out in the results in app. II.)

Student achievement on reading and mathematics were analyzed separately for each privately managed public school with its set of matched schools. The regression formula was:

$$
\begin{aligned}
& \text { Assessment Score }_{i}=\beta_{1 i}+\beta_{2 i} \text { School Type }+\beta_{3 i} \text { Mobility }+\beta_{4 i} \text { LEP }+ \\
& \beta_{5 i} \text { Special Education }+\beta_{6 i} \text { Low-income }+\beta_{7 i} \text { Race/Ethnicity }+\varepsilon_{i}
\end{aligned}
$$

where, (1) i is the individual student, (2) low-income is determined by eligibility for free and/or reduced lunch, and (3) race and ethnicity are distinct codes dependent upon the geographical area.

We also performed analyses on different groupings of the comparison schools in Denver, Cleveland, and St. Paul. In Denver, 2 of our matched schools were in a distinct neighborhood that school district personnel

\footnotetext{
${ }^{9}$ There are degrees of LEP; however, the data did not allow us to differentiate the degree of limitation.

${ }^{10}$ There are degrees of disability; however, the data did not allow us to differentiate for the degree or type of disability.

${ }^{11}$ In cities where both free and reduced-lunch variables were provided, the analysis considered them separately.
} 
believed might be atypical; in Cleveland and St. Paul several of the matched schools were magnet or former magnet schools. We re-analyzed the data in each of these cities using these groupings as factors. The overall results were unchanged, with the exception that in Denver, reading scores were not significantly different when the privately managed school was compared with the 2 schools not in the distinct neighborhood.

In Denver, San Francisco, and Phoenix, for the students in the grades we analyzed, we also obtained the prior years' reading scores if the student took the test in the same school. For this analysis, the regression formula used the difference between reading scores in the highest elementary grade and that of 2 years earlier as the dependent variable. The independent variables were similar to those employed in the cross sectional analysis with the exception that the reading/mathematics score for the period 2 years earlier was also included as an independent variable. The regression formula was:

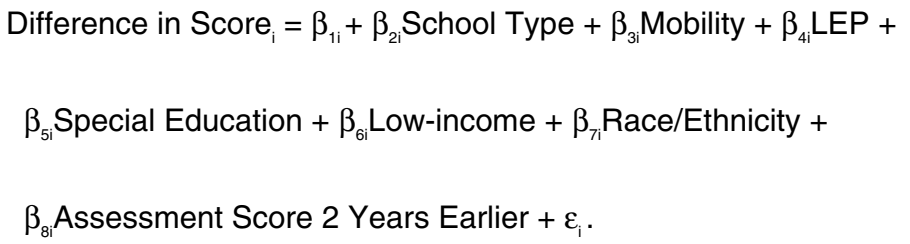

In conducting these analyses, we performed certain diagnostic and analytic tests to confirm both the appropriateness of aggregating categories in our analyses and the reasonableness of assumptions pertaining to normality and homogeneity of variance. In addition, we determined the extent of missing data and performed sensitivity analyses to assess the effect on our results. We determined that missing case level data had a negligible effect on our results.

To illustrate the magnitude of differences found, we computed effect sizes based on standardized mean differences. Using the OLS regression results, we divided the unstandardized coefficient associated with school type by the pooled standard deviation to obtain z-scores for average students in the privately managed and traditional schools. The reported percentile was the area of the normal curve associated with the z-scores.

Tables 5-12 in appendix II list the regression results and independent variables included in our analyses. The size and significance of the differences we report were derived from OLS regression models. We obtained results that were almost identical to the OLS results when we 
used robust estimation procedures to calculate the standard errors associated with the estimated differences. We also considered robust regression models that allowed for the clustering, and lack of independence, of students within schools. These models yielded somewhat fewer differences that were statistically significant at the 95-percent confidence level. We do not focus our reporting on the results of the models that account for clustering, however, since the statistical properties and validity of such models when applied to data with a very small number of clusters (in this case, 3 to 5 schools) is questionable. ${ }^{12}$ However, changes to significance levels of the school type coefficients due to robust standard errors and robust standard errors with clustering are noted in appendix II.

\section{Limitations of the Analysis}

The findings in this study are subject to typical limitations found in quasiexperimental designs. We examined the highest elementary grades tested for school years 2000-01 and 2001-02, and student achievement in these grades and years may not be indicative of student achievement in other grades and years in those schools. In addition, our matching process may not have produced equivalent groups for comparison. We mitigated this potential problem by using individual student characteristics in our analyses. However, reliable and complete student demographic data were not available in all sites, which resulted in the elimination of important factors from the model in several sites. In addition, other factors such as student ability, prior achievement, operating environment, reasons students enrolled in privately managed schools, and parental involvement, may be related to student achievement and are not accounted for in the study. Finally, our examination of student performance over time, that is, changes in achievement between grades, also has some limitations. First, the data allowed a study of achievement over time in only 3 of the 6 sites. In addition, the analyses included only students who continuously attended the school over the time period studied, and this in some cases eliminated more than half of the subjects from the analyses. We were

\footnotetext{
${ }^{12}$ See Jeffrey M. Wooldridge, Econometric Analysis of Cross Section and Panel Data (Cambridge: MIT Press, 2002), p.135.
} 
unable to determine whether those students who remained in the school for this period were different in some important way from those who left. 


\section{Appendix II: Tables of Regression Results for Differences in Student Achievement Scores on State Assessments}

Tables 5-12 in this appendix show the variables used in the OLS regression models and the results of those analyses. The results are presented separately by city and for each privately managed school and its particular set of matching traditional schools, with reading and math presented within the same table in all cases, except Detroit. The number of observations, shown as $\mathrm{N}$, is the total of the observations in the privately managed school and its set of comparison schools used in each regression analysis.

We also ran similar regression analyses using robust estimation procedures with and without clustering, as discussed in appendix I. In most cases, effects of school type remained significant at the 95-percent confidence level. Exceptions are indicated by table notes. 
Table 5: Regression Results for Differences in Student Performance on State Assessments at the Privately Managed and Comparison Schools in Denver

\begin{tabular}{|c|c|c|c|}
\hline Denver & & & \\
\hline \multicolumn{4}{|l|}{ Dependent variable: reading } \\
\hline \multicolumn{4}{|l|}{$\mathrm{N}=703$} \\
\hline \multicolumn{4}{|l|}{$F=22.112$ significance .000} \\
\hline Independent variable & Coefficient & Standard error & Significance \\
\hline Constant & 630.8 & 8.9 & \\
\hline Traditional school & -13.2 & 5.3 & $.014^{\mathrm{a}}$ \\
\hline Mobility & -15.7 & 4.8 & .001 \\
\hline Special education & -60.3 & 6.6 & .000 \\
\hline Limited English proficiency & -38.9 & 5.9 & .000 \\
\hline Free lunch eligible & -17.7 & 5.2 & .001 \\
\hline Reduced lunch eligible & 0.6 & 6.8 & .932 \\
\hline African American & -36.1 & 7.6 & .000 \\
\hline Latino & -24.4 & 8.3 & .003 \\
\hline Other minority & -35.8 & 16.3 & .028 \\
\hline \multicolumn{4}{|c|}{ Dependent variable: mathematics } \\
\hline \multicolumn{4}{|c|}{$\mathrm{N}=704$} \\
\hline \multicolumn{4}{|l|}{$F=22.120$ significance .000} \\
\hline Independent variable & Coefficient & Standard error & Significance \\
\hline Constant & 521.6 & 10.3 & \\
\hline Traditional school & -24.0 & 6.2 & $.000^{\mathrm{a}}$ \\
\hline Mobility & -14.4 & 5.5 & .009 \\
\hline Special education & -81.9 & 7.5 & .000 \\
\hline Limited English proficiency & -20.7 & 6.8 & .002 \\
\hline Free lunch eligible & -19.5 & 6.0 & .001 \\
\hline Reduced lunch eligible & 3.9 & 7.9 & .625 \\
\hline African American & -34.1 & 8.6 & .000 \\
\hline Latino & -24.1 & 9.5 & .011 \\
\hline Other minority & -1.9 & 18.7 & .921 \\
\hline
\end{tabular}

Source: GAO data analysis.

a Using robust standard error procedures with clustering, the effect of school type approaches but does not reach significance at the 95-percent confidence level. ( $p=0.06$ for reading; $p=0.09$ for math.) 
Table 6: Regression Results for Differences in Student Performance on State Assessments at the Privately Managed and Comparison Schools in San Francisco

\section{San Francisco}

Dependent variable: reading

$\mathrm{N}=388$

$F=6.158$ significance .000

Independent variable

Coefficient Standard error

Significance

\begin{tabular}{lccr}
\hline Constant & 651.9 & 7.1 & \\
\hline Traditional school & -7.8 & 3.4 & $.022^{\mathrm{a}}$ \\
\hline Mobility & -12.7 & 5.9 & .031 \\
\hline Special education & -18.5 & 7.9 & .019 \\
\hline Limited English proficiency & -19.5 & 3.8 & .000 \\
\hline Free lunch eligible & -3.5 & 3.8 & .362 \\
\hline Reduced lunch eligible & 2.6 & 6.3 & .684 \\
\hline African American & -17.8 & 7.6 & .020 \\
\hline Latino & 1.7 & 7.3 & .815 \\
\hline Asian & -8.9 & 7.5 & .237 \\
\hline Other minority & -17.3 & 8.9 & .052 \\
\hline
\end{tabular}

Dependent variable: mathematics

$\mathrm{N}=394$

F = 7.666 significance .000

\begin{tabular}{lccc}
\hline Independent variable & Coefficient & Standard error & Significance \\
\hline Constant & 658.0 & 7.1 & \\
\hline Traditional school & -13.3 & 3.3 & .000 \\
\hline Mobility & -14.5 & 5.8 & .013 \\
\hline Special education & -7.4 & 7.8 & .341 \\
\hline Limited English proficiency & -12.0 & 3.8 & .002 \\
\hline Free lunch eligible & -4.5 & 3.7 & .231 \\
\hline Reduced lunch eligible & -1.8 & 6.2 & .769 \\
\hline African American & -27.3 & 7.5 & .000 \\
\hline Latino & -5.3 & 7.2 & .467 \\
\hline Asian & -7.7 & 7.4 & .302 \\
\hline Other minority & -19.6 & 8.7 & .026 \\
\hline
\end{tabular}

Source: GAO data analysis.

a Using robust procedures with clustering, the effect of school type is no longer significant at the 95-percent confidence level. 
Table 7: Regression Results for Differences in Student Performance on State Assessments at the Privately Managed and Comparison Schools in Cleveland

\begin{tabular}{lrrr}
\hline Cleveland & & & \\
\hline Dependent variable: reading & & & \\
\hline $\mathbf{N}=\mathbf{6 3 1}$ & & & \\
\hline $\mathbf{F}=\mathbf{1 8 . 4 5 4}$ significance $\mathbf{. 0 0 0}$ & Coefficient & Standard error & Significance \\
\hline Independent variable & 192.7 & 5.7 & \\
\hline Constant & 15.6 & 2.1 & .000 \\
\hline Traditional school & 1.1 & 1.6 & .496 \\
\hline Mobility & -17.1 & 2.6 & .000 \\
\hline Special education & -0.4 & 1.7 & .815 \\
\hline Free lunch eligible & 3.9 & 3.2 & .233 \\
\hline Reduced lunch eligible & 0.8 & 5.1 & .876
\end{tabular}

Dependent variable:

mathematics

\begin{tabular}{lrrr}
\hline $\mathbf{N}=\mathbf{6 5 0}$ & & & \\
\hline $\mathbf{F}=\mathbf{1 9 . 2 8 9}$ significance $\mathbf{. 0 0 0}$ & Coefficient & Standard error & Significance \\
\hline Independent variable & 204.8 & 8.2 & \\
\hline Constant & 24.7 & 3.0 & .000 \\
\hline Traditional school & -1.4 & 2.3 & .551 \\
\hline Mobility & -19.3 & 3.6 & .000 \\
\hline Special education & -2.8 & 2.4 & .250 \\
\hline Free lunch eligible & 2.6 & 4.5 & .568 \\
\hline Reduced lunch eligible & -17.5 & 7.4 & .018 \\
\hline Minority & & & \\
\hline
\end{tabular}

Source: GAO data analysis. 
Table 8: Regression Results for Differences in Student Performance on State Assessments at the Privately Managed School and Comparison Schools in St. Paul (School A Comparison)

\begin{tabular}{l}
\hline St. Paul \\
\begin{tabular}{lrrr}
\hline Dependent variable: reading & & & \\
\hline $\mathbf{N}=\mathbf{4 5 9}$ & & & \\
\hline $\mathbf{F}=\mathbf{4 1 . 9 0 4}$ significance $\mathbf{0 0 0}$ & Coefficient & Standard error & Significance \\
\hline Independent variable & $1,478.6$ & 50.7 & \\
\hline Constant & 128.3 & 49.1 & .009 \\
\hline Traditional School & -160.1 & 33.8 & .000 \\
\hline Limited English proficiency & -114.3 & 23.2 & .000 \\
\hline Free/reduced lunch eligible & -149.5 & 25.8 & .000 \\
\hline African American & -41.9 & 31.9 & .191 \\
\hline Other minority & & &
\end{tabular}
\end{tabular}

Dependent variable: mathematics

$\mathrm{N}=452$

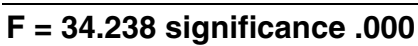

\begin{tabular}{lrrr}
\hline Independent variable & Coefficient & Standard error & Significance \\
\hline Constant & $1,368.4$ & 51.1 & \\
\hline Traditional school & 185.3 & 49.6 & .000 \\
\hline Limited English proficiency & -98.8 & 34.6 & .004 \\
\hline Free/reduced lunch eligible & -112.8 & 23.4 & .000 \\
\hline African American & -157.7 & 26.1 & .000 \\
\hline Other minority & -24.6 & 32.4 & .448 \\
\hline
\end{tabular}

Source: GAO data analysis.

Note: Special education data were available for only one school year and so were not included in the final analyses. Diagnostic analyses were run for the one year that special education data were available to test for the effects of including special education in the model. When special education was included, school type remained significant at the 95-percent confidence level. 
Table 9: Regression Results for Differences in Student Performance on State Assessments at the Privately Managed School and Comparison Schools in St. Paul (School B Comparison)

\begin{tabular}{lrrr}
\hline St. Paul & & & \\
\hline Dependent variable: reading & & & \\
\hline $\mathbf{N}=\mathbf{4 9 4}$ & & & \\
\hline $\mathbf{F}=\mathbf{2 2 . 0 6 1}$ significance $\mathbf{. 0 0 0}$ & Coefficient & Standard error & Significance \\
\hline Independent variable & $1,415.9$ & 36.1 & \\
\hline Constant & 90.5 & 33.5 & .007 \\
\hline Traditional school & -161.3 & 25.1 & .000 \\
\hline Limited English proficiency & -54.6 & 19.3 & .005 \\
\hline Free/reduced lunch eligible & -86.0 & 22.8 & .000 \\
\hline African American & 14.6 & 28.4 & .607 \\
\hline Other minority & & &
\end{tabular}

Dependent variable: mathematics

$\mathrm{N}=474$

$\mathrm{F}=\mathbf{1 8 . 8 8 3}$ significance .000

\begin{tabular}{lrrr}
\hline Independent variable & Coefficient & Standard error & Significance \\
\hline Constant & $1,343.0$ & 33.8 & \\
\hline Traditional school & 103.3 & 31.7 & .001 \\
\hline Limited English proficiency & -84.6 & 22.6 & .000 \\
\hline Free/reduced lunch eligible & -42.0 & 17.9 & .020 \\
\hline African American & -110.9 & 21.3 & .000 \\
\hline Other minority & 10.2 & 25.5 & .690 \\
\hline
\end{tabular}

Source: GAO data analysis.

Note: Special education data were available for only one school year and so were not included in the final analyses. Diagnostic analyses were run for the one year that special education data were available to test for the effects of including special education in the model. When special education was included, school type remained significant at the 95-percent confidence level. 
Table 10: Regression Results for Differences in Student Performance on State Assessments at the Privately Managed and Comparison Schools in Phoenix

\begin{tabular}{lrrr}
\hline Phoenix & & & \\
\hline Dependent variable: reading & & & \\
\hline $\mathbf{N}=\mathbf{8 3 8}$ & Coefficient & Standard error & Significance \\
\hline $\mathbf{F}=\mathbf{1 6 . 3 0 4}$ significance $\mathbf{. 0 0 0}$ & 646.6 & 4.0 & \\
\hline Independent variable & -3.9 & 2.5 & .116 \\
\hline Constant & -15.5 & 2.1 & .000 \\
\hline Traditional school & -12.1 & 5.2 & .019 \\
\hline Mobility & -12.8 & 3.7 & .001 \\
\hline African American & -1.1 & 5.2 & .831 \\
\hline Latino & & & \\
\hline Other minority & & & \\
\hline Dependent variable: mathematics & & & \\
\hline $\mathbf{N}=\mathbf{8 8 2}$ & Coefficient & Standard error & Significance \\
\hline F = 9.931 significance .000 & 637.6 & 4.0 & .010 \\
\hline Independent variable & 0.8 & 2.5 & .765 \\
\hline Constant & -12.7 & 2.1 & .000 \\
\hline Traditional school & -13.8 & 5.3 & \\
\hline Mobility & & & \\
\hline African American & & & \\
\hline Latino & & & \\
\hline Other minority & & & \\
\hline Source: GAO data analysis. & & & \\
\hline
\end{tabular}

Note: Special education and limited English proficiency were removed as independent variables because the data received were considered unreliable. 
Table 11: Regression Results for Differences in Student Performance on State Reading Assessment at the Privately Managed and Comparison Schools in Detroit

\section{Detroit - Privately Managed School A}

$\mathrm{N}=208$

$F=6.428$ significance .000

\begin{tabular}{lrrr}
\hline Independent variable & Coefficient & Standard error & Significance \\
\hline Constant & 309.8 & 7.3 & \\
\hline Traditional school & 11.6 & 3.2 & $.000^{\mathrm{a}}$ \\
\hline African American & -16.2 & 6.9 & .020 \\
\hline Other minority & -10.0 & 10.2 & .327
\end{tabular}

Detroit - Privately Managed School B

$\mathrm{N}=176$

F = 1.361 significance .257

\begin{tabular}{lrrr}
\hline Independent variable & Coefficient & Standard error & Significance \\
\hline Constant & 294.6 & 12.3 & \\
\hline Traditional school & -9.0 & 4.6 & $.054^{\mathrm{a}, \mathrm{b}}$ \\
\hline African American & 7.1 & 12.0 & .556 \\
\hline Other minority & 12.9 & 26.5 & .627
\end{tabular}

Detroit - Privately Managed School C

$\mathbf{N}=339$

$F=19.182$ significance .000

\begin{tabular}{lrrr}
\hline Independent variable & Coefficient & Standard error & Significance \\
\hline Constant & 306.3 & 1.9 & \\
\hline Traditional school & -10.1 & 2.3 & $.000^{\mathrm{a}}$
\end{tabular}

Detroit - Privately Managed School D

$\mathrm{N}=\mathbf{4 1 8}$

F $=4.263$ significance .000

Independent variable Coefficient Standard error Significance

Constant $285.2 \quad 14.7$

Traditional school

6.8

2.1

African American

6.3

14.6 .666

Other minority

32.0

25.2

.205


Appendix II: Tables of Regression Results for

Differences in Student Achievement Scores

on State Assessments

\section{Detroit - Privately Managed School E}

$\mathbf{N}=186$

$\mathbf{F}=\mathbf{3 . 4 5 0}$ significance $\mathbf{0 1 8}$

\begin{tabular}{lrrr}
\hline Independent variable & Coefficient & Standard error & Significance \\
\hline Constant & 300.8 & 16.9 & \\
\hline Traditional school & 9.2 & 2.9 & $.002^{\mathrm{a}}$ \\
\hline African American & -3.5 & 16.7 & .836 \\
\hline Other minority & -7.1 & 19.3 & .712
\end{tabular}

Detroit - Privately Managed School F

$\mathrm{N}=\mathbf{3 0 0}$

$F=6.536$ significance .002

Independent variable

Coefficient

Standard error

Significance

\begin{tabular}{lrrr}
\hline Constant & 286.8 & 2.4 & \\
\hline Traditional school & 9.3 & 2.8 & $.001^{\mathrm{a}}$ \\
\hline Other minority & -23.3 & 21.4 & .276
\end{tabular}

Detroit - Privately Managed School G

$\mathrm{N}=\mathbf{2 2 9}$

F = 5.014 significance .002

Independent variable

Coefficient

Standard error

Significance

\begin{tabular}{lrrr}
\hline Constant & 273.0 & 14.2 & \\
\hline Traditional school & 12.4 & 3.3 & $.000^{\mathrm{a}}$ \\
\hline African American & 11.9 & 14.2 & .405 \\
\hline Other minority & 18.8 & 16.7 & .262
\end{tabular}

Detroit - Privately Managed School H

$\mathrm{N}=367$

$F=12.531$ significance .000

\begin{tabular}{lrrr}
\hline Independent variable & Coefficient & Standard error & Significance \\
\hline Constant & 283.8 & 3.0 & \\
\hline Traditional school & 12.4 & 2.4 & .000 \\
\hline African American & -5.2 & 4.2 & .214 \\
\hline Other minority & 7.9 & 6.7 & .235 \\
\hline Latino & -0.3 & 2.6 & .893 \\
\hline Limited English proficiency & -25.6 & 4.2 & .000 \\
\hline
\end{tabular}

Source: GAO data analysis.

Note: Where results do not include race or ethnic variables, all students at the privately managed school and comparable schools used in the regression analysis were African American. 
Appendix II: Tables of Regression Results for

Differences in Student Achievement Scores

on State Assessments

${ }^{a}$ Using robust standard error procedures with clustering, the effect of school type is not significant at the 95-percent confidence level.

${ }^{b}$ Using robust estimation procedures without clustering, the effect of school type is significant at the 95-percent confidence level. 
Table 12: Regression Results for Differences in Student Performance on State Math Assessment at the Privately Managed and Comparison Schools in Detroit

\begin{tabular}{|c|c|c|c|}
\hline \multicolumn{4}{|c|}{ Detroit - Privately Managed School A } \\
\hline \multicolumn{4}{|c|}{$N=208$} \\
\hline \multicolumn{4}{|c|}{$F=8.573$ significance .000} \\
\hline Independent variable & Coefficient & Standard error & Significance \\
\hline Constant & 529.4 & 12.2 & \\
\hline Traditional school & 25.7 & 5.4 & $.000^{\mathrm{a}}$ \\
\hline African American & -15.2 & 11.5 & .188 \\
\hline Other minority & -6.0 & 16.9 & .721 \\
\hline \multicolumn{4}{|c|}{ Detroit - Privately Managed School B } \\
\hline \multicolumn{4}{|c|}{$\mathrm{N}=176$} \\
\hline \multicolumn{4}{|c|}{$F=2.967$ significance $.0-34$} \\
\hline Independent variable & Coefficient & Standard error & Significance \\
\hline Constant & 522.0 & 17.0 & \\
\hline Traditional school & -18.6 & 6.4 & $.004^{a}$ \\
\hline African American & 9.9 & 16.5 & .549 \\
\hline Other minority & 23.7 & 36.5 & .518 \\
\hline
\end{tabular}

Detroit - Privately Managed School C

$\mathrm{N}=342$

$\mathrm{F}=13.258$ significance .000

Independent variable Coefficient Standard error Significance

\begin{tabular}{lrrr}
\hline Constant & 524.5 & 3.0 & \\
\hline Traditional school & 13.6 & 3.7 & $.000^{\mathrm{a}}$
\end{tabular}

Detroit - Privately Managed School D

$\mathrm{N}=420$

$\mathbf{F}=22.959$ significance .000

Independent variable Coefficient Standard error Significance

\begin{tabular}{lrrr}
\hline Constant & 512.0 & 20.2 & \\
\hline Traditional school & 23.5 & 2.8 & .000 \\
\hline African American & -3.1 & 20.0 & .876 \\
\hline Other minority & -0.5 & 34.6 & .988 \\
\hline
\end{tabular}


Appendix II: Tables of Regression Results for

Differences in Student Achievement Scores

on State Assessments

\begin{tabular}{|c|c|c|c|}
\hline Detroit - Privately Manage & & & \\
\hline$N=188$ & & & \\
\hline$F=2.977$ significance .03 & & & \\
\hline Independent variable & Coefficient & Standard error & Significance \\
\hline Constant & 572.1 & 28.7 & \\
\hline Traditional school & 10.9 & 4.9 & $.028^{\mathrm{a}}$ \\
\hline African American & -54.4 & 28.3 & .056 \\
\hline Other minority & -58.5 & 34.6 & .092 \\
\hline Detroit - Privately Manage & & & \\
\hline $\mathbf{N}=297$ & & & \\
\hline$F=41.445$ significance .0 & & & \\
\hline Independent variable & Coefficient & Standard error & Significance \\
\hline Constant & 500.2 & 3.7 & \\
\hline Traditional school & 37.9 & 4.2 & .000 \\
\hline Other minority & -16.2 & 31.3 & .606 \\
\hline Detroit - Privately Manage & & & \\
\hline$N=231$ & & & \\
\hline$F=4.644$ significance .00 & & & \\
\hline Independent variable & Coefficient & Standard error & Significance \\
\hline Constant & 505.7 & 20.4 & \\
\hline Traditional school & 17.7 & 4.8 & .000 \\
\hline African American & 7.0 & 20.4 & .731 \\
\hline Other minority & 15.7 & 24.0 & .515 \\
\hline Detroit - Privately Manage & & & \\
\hline $\mathbf{N}=366$ & & & \\
\hline$F=19.86$ significance .00 & & & \\
\hline Independent variable & Coefficient & Standard error & Significance \\
\hline Constant & 498.8 & 4.1 & \\
\hline Traditional school & 27.0 & 3.3 & .000 \\
\hline African American & -5.1 & 5.7 & .368 \\
\hline Other minority & 12.7 & 9.0 & .160 \\
\hline Latino & 0.3 & 3.5 & .934 \\
\hline Limited English proficiency & -33.2 & 5.6 & .000 \\
\hline
\end{tabular}

Note: Where results do not include race or ethnic variables, all students at the privately managed school and comparable schools used in the regression analysis were African American. 
Appendix II: Tables of Regression Results for

Differences in Student Achievement Scores

on State Assessments

${ }^{a}$ Using robust standard error procedures with clustering, the effect of school type is not significant at the 95-percent confidence level. 


\section{Appendix III: Characteristics of Privately Managed Schools and Comparable Traditional Public Schools in Detroit}

\begin{tabular}{|c|c|c|c|c|}
\hline $\begin{array}{l}\text { Privately Managed/ } \\
\text { traditional }\end{array}$ & Enrollment & $\begin{array}{l}\text { Percent free } \\
\text { and reduced }\end{array}$ & $\begin{array}{r}\text { Percent } \\
\text { special ed }\end{array}$ & $\begin{array}{l}\text { Percent } \\
\text { minority }\end{array}$ \\
\hline Private - $\mathrm{A}$ & 867 & 68 & 3 & 100 \\
\hline Traditional - A & 693 & 81 & 4 & 100 \\
\hline Traditional - B & 538 & 58 & 3 & 100 \\
\hline Traditional - C & 594 & 78 & 5 & 99 \\
\hline Private - B & 354 & 79 & 11 & 99 \\
\hline Traditional - A & 594 & 78 & 5 & 99 \\
\hline Traditional - B & 158 & 79 & 7 & 100 \\
\hline Traditional - C & 389 & 74 & 3 & 98 \\
\hline Private - C & 322 & 39 & 8 & 99 \\
\hline Traditional - A & 485 & 43 & 12 & 100 \\
\hline Traditional - B & 434 & 47 & 4 & 100 \\
\hline Traditional - C & 446 & 65 & 5 & 95 \\
\hline Private - D & 1108 & 46 & 3 & 100 \\
\hline Traditional - A & 538 & 58 & 3 & 100 \\
\hline Traditional - B & 369 & 47 & 4 & 99 \\
\hline Traditional - C & 677 & 53 & 2 & 99 \\
\hline Private - E & 368 & 70 & 9 & 100 \\
\hline Traditional - A & 389 & 74 & 3 & 98 \\
\hline Traditional - B & 487 & 67 & 5 & 100 \\
\hline Traditional - C & 524 & 62 & 5 & 100 \\
\hline Private - F & 319 & 75 & 7 & 95 \\
\hline Traditional - A & 214 & 68 & 7 & 89 \\
\hline Traditional - B & 389 & 74 & 3 & 98 \\
\hline Traditional - C & 451 & 80 & 0 & 98 \\
\hline Private - G & 716 & 37 & 3 & 100 \\
\hline Traditional - A & 538 & 58 & 3 & 100 \\
\hline Traditional - B & 677 & 53 & 2 & 100 \\
\hline Traditional - C & 369 & 47 & 4 & 100 \\
\hline Private - H & 452 & 46 & 10 & 79 \\
\hline Traditional - A & 561 & 73 & 0 & 76 \\
\hline Traditional - B & 705 & 65 & 2 & 72 \\
\hline Traditional - C & 586 & 84 & 2 & 76 \\
\hline
\end{tabular}

Sources: GAO data analysis from Common Core of Data school year 2000-01 unless otherwise noted. Special education data were from school Web sites. Limited English proficiency data were not available. 


\section{Appendix IV: GAO Contacts and Staff Acknowledgments}

Sloane, and Shana Wallace made key contributions to this report. Deidre M. McGinty and Randolph D. Quezada also provided important support. 


\section{Related GAO Products}

Title I: Characteristics of Tests Will Influence Expenses; Information Sharing May Help States Realize Efficiencies. GAO-03-389. Washington, D.C.: May 8, 2003.

Public Schools: Insufficient Research to Determine Effectiveness of Selected Private Education Companies. GAO-03-11. Washington, D.C.: October 29, 2002.

School Vouchers: Characteristics of Privately Funded Programs. GAO-02-752. Washington, D.C.: September 10, 2002.

Title I: Education Needs to Monitor States' Scoring of Assessments. GAO-02-393. Washington, D.C.: April 1, 2002.

School Vouchers: Publicly Funded Programs in Cleveland and Milwaukee. GAO-01-914. Washington, D.C.: August 31, 2001.

Charter Schools: Limited Access to Facility Financing. GAO/HEHS-00-163. Washington, D.C.: September 12, 2000.

Charter Schools: Federal Funding Available but Barriers Exist. GAO/HEHS-98-84. Washington, D.C.: April 30, 1998.

Charter Schools: Recent Experiences in Accessing Federal Funds. GAO/T-HEHS-98-129. Washington, D.C.: March 31, 1998.

Charter Schools: Issues Affecting Access to Federal Funds. GAO/T-HEHS-97-216. Washington, D.C.: September 16, 1997.

Private Management of Public Schools: Early Experiences in Four School Districts. GAO/HEHS-96-3. Washington, D.C.: April 19, 1996. 


\section{GAO's Mission}

The General Accounting Office, the audit, evaluation and investigative arm of Congress, exists to support Congress in meeting its constitutional responsibilities and to help improve the performance and accountability of the federal government for the American people. GAO examines the use of public funds; evaluates federal programs and policies; and provides analyses, recommendations, and other assistance to help Congress make informed oversight, policy, and funding decisions. GAO's commitment to good government is reflected in its core values of accountability, integrity, and reliability.

\section{Obtaining Copies of GAO Reports and Testimony}

The fastest and easiest way to obtain copies of GAO documents at no cost is through the Internet. GAO's Web site (www.gao.gov) contains abstracts and fulltext files of current reports and testimony and an expanding archive of older products. The Web site features a search engine to help you locate documents using key words and phrases. You can print these documents in their entirety, including charts and other graphics.

Each day, GAO issues a list of newly released reports, testimony, and correspondence. GAO posts this list, known as "Today's Reports," on its Web site daily. The list contains links to the full-text document files. To have GAO e-mail this list to you every afternoon, go to www.gao.gov and select "Subscribe to e-mail alerts" under the "Order GAO Products" heading.

\section{Order by Mail or Phone}

The first copy of each printed report is free. Additional copies are $\$ 2$ each. A check or money order should be made out to the Superintendent of Documents. GAO also accepts VISA and Mastercard. Orders for 100 or more copies mailed to a single address are discounted 25 percent. Orders should be sent to:

\section{U.S. General Accounting Office \\ 441 G Street NW, Room LM \\ Washington, D.C. 20548}

$\begin{array}{lll}\text { To order by Phone: } & \text { Voice: } & \text { (202) } 512-6000 \\ & \text { TDD: } & (202) 512-2537 \\ & \text { Fax: } & \text { (202) } 512-6061\end{array}$

\section{To Report Fraud, Waste, and Abuse in Federal Programs} Contact:

Web site: www.gao.gov/fraudnet/fraudnet.htm E-mail: fraudnet@gao.gov Automated answering system: (800) 424-5454 or (202) 512-7470 